Canadian University Music Review

Canadian University Music Review

Revue de musique des universités canadiennes

\title{
What News on the Rialto? Fundraising and Publicity for Operas in Seventeenth-Century Venice
}

\section{Sandy Thorburn}

Volume 23, numéro 1-2, 2003

URI : https://id.erudit.org/iderudit/1014523ar

DOI : https://doi.org/10.7202/1014523ar

Aller au sommaire du numéro

\section{Éditeur(s)}

Canadian University Music Society / Société de musique des universités canadiennes

ISSN

0710-0353 (imprimé)

2291-2436 (numérique)

Découvrir la revue

Citer cet article

Thorburn, S. (2003). What News on the Rialto? Fundraising and Publicity for Operas in Seventeenth-Century Venice. Canadian University Music Review / Revue de musique des universités canadiennes, 23(1-2), 166-200.

https://doi.org/10.7202/1014523ar
Résumé de l'article

On décrit généralement les opéras commerciaux du XVII ${ }^{\mathrm{e}}$ siècle à Venise, soit les premiers opéras publics, comme étant rigoureusement littéraires entre 1637 et 1660 . Divers moyens, dont les décors, les machines et les formes musicales, aidaient les auditeurs issus de classes et de lieux différents à comprendre ces divertissements typiques du carnaval de Venise. Leur objectif - créer un divertissement commercial qui reflète et souligne les merveilles de Venise - a rapidement été cerné par l'histoire de l'opéra commercial vénitien. Le présent article cherche à définir jusqu'à quel degré les entreprises commerciales naissantes, comme les journaux, la poste, l'édition et la publicité, définissaient le contenu et la nature de ces premières œuvres lyriques.
All Rights Reserved ( C Canadian University Music Society / Société de musique des universités canadiennes, 2004
Ce document est protégé par la loi sur le droit d'auteur. L’utilisation des services d'Érudit (y compris la reproduction) est assujettie à sa politique d'utilisation que vous pouvez consulter en ligne.

https://apropos.erudit.org/fr/usagers/politique-dutilisation/ 
WHAT NEWS ON THE RIALTO? FUNDRAISING AND PUBLICITY FOR OPERAS IN SEVENTEENTH-CENTURY VENICE

\section{Sandy Thorburn}

\section{INTRODUCTION}

The standard literature about commercial opera production in seventeenthcentury Venice describes a developmental trajectory through the century from rigorous literary and musical art to performer-based spectacle or formulaic artifice by the time the Arcadian Academy took control of opera aesthetics in the 1690s. Such a trajectory is both compelling to trace and relatively difficult to substantiate; many operas in the 1690s are somewhat musically and poetically formulaic; composers and librettists had developed a number of formulae-the da capo aria, the exit aria, the ground bass lament or love duet-that allowed the inattentive listener to capture the gist of the plot while admiring the special effects. Virtually everything visual about opera in the late seventeenth-century was designed to elicit wonder, from the sets, machinery, costumes, and lighting, to the theatre itself. Monteverdi/Busenello's L'incoronazione di Poppea (1643), an early Venetian opera, was a first-rate musical setting of an excellent libretto, but this work was not representative of the quality of operatic work in the 1640 s, either musically or dramatically.

In point of fact, what is known about most of these early operas-by the admission of their librettists, composers, audience members, and scenic designers-suggests that they were just as concerned with special effects, even to the detriment of music and poetry, as the later operas of the 1690 s were. Badoaro suggests in his preface to Ulisse errante (1644), that "at one time changes of place were abhorred in these plays, but at present, in order to please the eyes, what was once prohibited seems to be prescribed...." (Rosand 1991, 49). ${ }^{1}$ Vincenzo Nolfi justifies in the preface to his libretto to Bellerofonte: "the tale that was crumbling because of its antiquity has been restored to life by my pen in a dramatic form, under the constraint of very little time, in order to be crowned by the beauty of the theatrical machines and sets" (Rosand 1991, 100). ${ }^{2}$ It seems that the goal-to create a commercial entertainment industry that reflected and highlighted the wonders of Venice-was identified early in the history of Venetian commercial opera. 
For the purposes of this study, the term "commercial" is not necessarily synonymous with "profitable"; many recent studies of Venetian commercial opera have noted that profit-making was a secondary consideration for those most involved in its creation as this letter in Le Mercure galant shows: "The great public theatres are reserved for the operas that the nobles or others compose to their own desires, more for their own diversion than for the profits they earn, which do not furnish even a half of their costs." ${ }^{3}$ Given this state of affairs, the term refers to the fact that there was a public who paid for the privilege of admission, rather than being invited, as they had been in courtly spectacle productions. Thus, enterprises produced with a paying public in mind, whose design and production were in some way determined by considerations of the public can be regarded as commercial productions, because they had profit making as their principal economic goal (Worsthorne 1954). ${ }^{4}$

Venetian commercial opera began in 1637 and quickly became the most popular form of entertainment among wealthy Europeans, Venetian or foreign, in a city teeming with entertainment. Henry Prunières has suggested that the Roman machine-opera was imported by Manelli and Ferrari and adapted to the needs of the Venetian tourist industry. ${ }^{5}$ Indeed, the Venetian practitioners of this modified Roman machine-opera began exporting it to neighbouring cities shortly after it had established a foothold in Venice, reaching as far afield as France and Germany by the 1650 s. $^{6}$ Its sudden and enduring popularity had several causes and long-term effects, both on Venice and on the nature of musico-dramatic entertainment. The initial attempts at turning what had hitherto been a plaything of extremely wealthy monarchs into a viable business turned out to be difficult, and the efforts of Francesco Cavalli, Marco and Giovanni Faustini graphically demonstrate the growing pains of the industry. The first steps toward creating a profitable industry were made by the wealthy

3“... les grands [Thêâtres publics] sont destinez pour les Opéra que ces Nobles, ou d'autres font fair et composer à leurs frais, plutost pour leur divertissement particulier, que pour le profit qu'ils en retirent, qui ne fournit pas d'ordinaire à la moitié de la dépense." (February 20, 1683.) Repr. in Vaumorière $(1709,429)$.

4The author, one of the earliest scholars to speak of the Venetian commercial opera, drew a clear distinction between courtly spectacles and Venetian commercial operas. Indeed, he goes so far as to suggest that there was no such concept as a "general public" in opera before 1637. In the preface to his book $(1954, v)$, he writes: "To speak of the general public in connexion with opera before 1637 is perhaps an anachronism. For performance was then confined, for reasons of expense and social custom, to the numerous European courts ... Venetian noblemen formed companies to build and speculate in opera houses, and the rows of boxes were rented by their friends or by travellers who flocked to the city to enjoy the new art. There is no question of distinguishing the kind of audience that attended these performances with the audience of an older generation. The importance of the opening of the public opera house lies rather in the permanent employment it gave to musicians."

5 "Benedetto Ferrari and Francesco Manelli introduced to Venice the sort of Roman machine operas that had swept the rest of Italy. This genre quickly evolved and took on a new, uniquely Venetian aspect." ["Benedetto Ferrari et Francesco Manelli avait introduit à Venise l'Opéra à machines des Romains, tel qu'il régnait alors dans toute l'Italie. Très rapidement ce genre allait évoluer et prendre un aspect nouveau proprement vénitien."] (Prunières 1931, 46.)

6There is a detailed description of the theatres built on the Venetian model in Bianconi and Pestelli $(1998,7-31)$. 
and influential noble Venetian family, the Grimani of Santa Maria Formosa. They began by owning several Venetian theatres, and finished the century with a virtual monopoly over the entire industry. During the 1680 s, they controlled most of the major theatres in Venice-the SS Giovanni e Paolo, the sumptuous San Giovanni Grisostomo and even the San Salvatore theatre-as impresarios, owners and even librettists. The other major figure in the opera business of the mid-seventeenth-century was Francesco Santurini, a resourceful middle-class businessperson of the popolano class, ${ }^{7}$ who cleverly undercut his competitors, thereby increasing his theatre's (the San Moisè) popularity. He managed to parlay this popularity into financial backing to build a new theatre-the Sant'Angelo. The hubris of his financial ruin is tragic: he was defeated by the very class structure he had challenged.

One element that helped turn commercial opera into a modern mercantilist institution was the advent of the newspaper industry. This industry informed people of events they needed to know about in good society, turning a relatively obscure production at an equally obscure theatre in Venice into a popular topic of conversation among the upper classes of Europe. Commercial enterprise is dependent on communication because business needs customers, and customers will buy a product only if they know it exists. In the case of opera, customers had first to be informed, and then lured to the theatres. In order to describe the methods used by Venetian opera producers to make audience members aware of their productions, it is necessary to determine who these producers and their target audiences were: the sender and the recipient of the publicity. I will briefly outline the major figures in the business, the target audience and methods of publicizing the works with an eye to critically examining this belief.

\section{IMPRESARIOS AND THEATRE OWNERS}

The first production team in Venetian commercial opera was led by Benedetto Ferrari and Francesco Manelli for the production of Andromeda at the San Cassiano theatre during Carnevale of $1637 .{ }^{8}$ This troupe had produced the opera Ermiona during a tournament in Padua on April 11, 1636, prompting them to try their luck in the capital city. Although the ten participants in this business venture financed most of the opera themselves, ${ }^{9}$ there appear to have

7 Venice, at the time had three distinct classes: the nobili, who were a group of old families belonging to the Grand Council of Venice, and who were thus involved in the politics of the state; the cittadino class, who were composed of civil servants, lawyers, notaries, and some doctors; and the popolani, who were the rest of the people of various social classes.

8 According to the libretto, which is dated May 1637, the opera was performed "già son due mesi" [already finished for two months], which suggests that it was performed in March. Carnevale ended on February 24 in that year though, so it was likely performed in February 1637.

9 Madalena Manelli from Rome played Andromeda, Francesco Angeletti of Assisi played Giunone, Annibale Graselli from Città di Castello played Mercurio and Perseo, Francesco Manelli, Madalena's husband, also from Rome wrote the libretto and played Nettuno, the Bolognese singer Giovanni Battista Bisucci played Protheo and Giove, the Roman Anselmo Marconi played Venere and Girolamo Medici from Rome played Astrea. Ferrari accompanied on the theorbo. Other than the Manellis, all the singers in this troupe were employed at San Marco. Giovanni Battista Balbi, the dancer and choreographer, and (probably) Giuseppe Alabardi, the scenic designer, were both Venetians. 
been other investors who were wealthy Venetian noblemen, like Ettore and Francesco Tron, owners of the San Cassiano (nuovo) theatre. ${ }^{10}$ The Trons applied for and were granted permission to re-open their theatre in May 1636; the terms stated that they were to offer entertainment to a "distinguished public" (l'insigni pubblici).

We do not know how much it cost to mount this first production, but the second production, La maga fulminata, produced by essentially the same group, ${ }^{11}$ cost a mere 2,000 scudi, or 19,200 Venetian lire (V1). ${ }^{12}$ This amount was what was invested by the players in the company, and would probably represent the cost of the sets and machinery, the rental of the theatre, and the salaries of the people involved. Shortly after this second production closed, the troupe split up: Manelli and Ferrari moved to the newly refurbished SS Giovanni e Paolo theatre, owned by Giovanni Grimani, leaving several members of their original troupe at San Cassiano to form an "Accademia per recitar l'Opera a S Cassan" on April 14, 1638. ${ }^{13}$ Although the act of constitution stipulates that the prima donna Felicita Uga was the leader of this academy, the composer Francesco Cavalli was its de facto head, performing the majority of the impresario's work at San Cassiano from 1639-45.

The first production of this new accademia was the opera Le nozze di Teti e di Peleo (premiered January 24, 1639). In order to have sufficient funding to present the work, three members of the accademia-Balbi, Bisucci and Persiani-acquired a loan from a pharmacist named Ghirardini, but Cavalli, who had signed the agreement, was left with full responsibility for the company's financial affairs. The only really significant information about this work is that it was the first in a series that Cavalli produced costing him a great deal of his

10The published libretto contains a note to the reader, which reads: "Dedicated to the glory of the musicians who, numbering but six, (together with the author) have presented Andromeda with great magnificence, and exquisiteness, at their own expense, and with some other consideration. I decided that it needed to have a brief account in this form to provide a taste for those who have not seen it." ["A Gloria de' Signori Musici ch'al numero di sei (coll'Autore collegati) hanno con gran magnificenza, ed' esquisitezza, à tutte loro spese, e di qualche consideratione, rappresentata l'Andromeda, e per gusto non meno, di chi non l'hà veduta, hò stimato cosa convenevole il farne un breve racconto in questa forma."]

11 Francesco and Madalena Manelli, Ferrari, Alabardi, Angeletti, and Bisucci were from the cast of Andromeda, while Felicita Uga (from Rome), Antonio Panni (from Reggio) and Guido Antonio Boretti (from Gubbio) were new to this production.

12This information is mentioned in the publisher's preface to the libretto, published by Bariletti ( 6 February 1638, 5) (provided in Italian in Rosand 1991, 407): "Readers, welcome the noble work of an eminent author, that has been able, with a mere five musicians, to delight the souls of its audience, at a cost of no more than 2000 scudi, with such a regal production as this; a similar production by a prince would have cost infinitely more money." Translation by the author of this article. ["Accoglietela, Lettori, come nobilissimo parto uscito da Autore insigne, quale hà potuto del suo, e con quello di cinque soli Musici Compagni con spesa, non più, di due mila scudi, rapir gli animi à gli Ascoltanti colla reale rappresentatione di quella; operationi simili à Prencipi costano infinito danaro."]

13 The entire group included Felicita Uga, a Roman singer who had been in both the Paduan production of Ermiona and La maga fulminata; Giovanni Battista Bisucci, a Bolognese singer who had been in Andromeda and La maga fulminata; the poet Orazio Persiani, living in Venice, although originally a Florentine; the Venetian choreographer and dancer Giovanni Battista Balbi who had appeared in Andromeda and La maga fulminata, and the Venetian composer Francesco Cavalli. 
own money. The other members of the accademia vanished from the scene, leaving Cavalli with personal debts to several (unnamed) gilt and cloth manufacturers, and a wood supplier named Pellizzarol. In 1644, Cavalli surrendered the property and theatrical equipment of the accademia to Ettore Tron (one of the owners of the theatre), Luca Francesco Barbaro, and Polo Boldù in exchange for 800 ducats. ${ }^{14} \mathrm{He}$ then made himself available for hire as a professional musician to be paid for completed work. Apparently, his interest in the financially unstable career of impresario was dampened considerably, although there is documentary evidence that he did go on to act as impresario at the San Cassiano theatre. ${ }^{15}$

This system of producing opera still required an impresario though, and the Tron-Barbaro-Boldù company needed a producer. There is a period after 1644 in which the identity of the San Cassiano impresario is unclear; the young librettist Giovanni Faustini became impresario at San Moisè in 1647 and was probably the impresario at Cassiano after Cavalli got out of the business, although I have not been able to substantiate this. ${ }^{16}$ If he did, both Doriclea and Titone (both produced in 1645) were his unsuccessful productions, suggesting that Cavalli may have saved himself from financial ruin by exiting the scene when he did. If not, the Tron-Barbaro-Boldù group probably underwrote these productions. Either way, on April 25, 1648, Rocco Maestri and Bortolo Castoreo signed an agreement to take over the management of the property and its attendant obligations. This agreement suggests that Francesco Tron and the two impresarios were obliged to repay 246 ducats owed to Cavalli since 1644 (four years before).

The Teatro Novissimo, the first theatre built expressly for opera production, was brought into being on May 30, 1640 when various noblemen joined Luigi Michiel ${ }^{17}$ in signing a contract to lease land owned by the monks of the monastery of SS Giovanni e Paolo located at the Mendicanti beside the Fondamenta Nuove (just north-east of the church of SS Giovanni e Paolo). The creative forces behind this operatic business venture were members of the Accademia degli Incogniti, particularly the writer Giulio Strozzi. They hired a group of performers from Rome, including Anna Renzi, the noted soprano, to mount their inaugural production, Strozzi's La finta pazza, set to music by Francesco Sacrati. As head of this troupe of performers, Sacrati began to produce operas at the Teatro Novissimo beginning with Bellerofonte (1642, libretto by Vincenzo Nolfi) and Venere gelosa (1643, libretto by Niccolo Enea

14 Clause (b) of this document stipulates that the nobles would pay him 800 ducats $(5120$ Venetian lire) for this, as well as assuming the debts that had accumulated "negli ultimi anni" but that they would deduct this amount from the 800 ducats owed to him. Somehow, although this had been agreed to, and although the total was assessed at 674 ducats $(4310 \mathrm{Vl})$, Cavalli was left with various debts, the most serious of which was to Pellizzarol, who initiated several court actions, but who was finally paid in full in 1650 .

15This story is related in Morelli and Walker (1976, 97-120), by means of a series of very informative documents from the incorporation to the dissolution of this accademia.

16See Rosand (1991, 170n36) and Biggi (2000, 39). It seems that Cavalli was impresario of both the San Cassiano and the San Moise in 1642.

17 These people were described in the contract as "diversi cavalieri." 
Bartolini). ${ }^{18}$ Shortly thereafter he moved to the SS Giovanni e Paolo theatre, where he contributed to Strozzi's La finta savia (1643) and wrote music for Badoaro's Ulisse errante (1644). When the Dominican friars who owned the warehouse in which the theatre was housed insisted that it be dismantled, it was taken apart, as stipulated in the contract, bringing to an end the shortest-lived, but most important theatre in the establishment of opera in the seventeenth-century. ${ }^{19}$

Almorò Zane was the owner of the relatively small and intimate San Moisè theatre, and it is possible that he was its first producer. Nothing is known about the production of Rinuccini's 1608 opera L'Arianna in $1639-40,{ }^{20}$ but Benedetto Ferrari probably became impresario at San Moisè in 1640, producing Il pastor regio (1640) and La ninfa avara (1641). He may have continued working there until 1644 when he moved to Parma. Between 1645 and 1647, many theatres were closed down by order of the Doge because of the War of Candia (there was a tradition in Venice to close theatres during war-time). Librettist Giovanni Faustini implies in his preface to Oristeo that he had produced two of his works at the San Moisè in 1648 (Ersilla) and 1649 (Euripo):

I wrote Oristeo and Rosinda, however, without my usual impetus, devoting little time to their creation, in order to free myself from the debts that inadvertently enclosed me within the confines of a theater where, if nothing else, the eye accustomed to the spaciousness of royal scenes [scene reali] became disillusioned by the proximity of the set. It is true that the abovementioned theater, in which Ersilla and Euripo appeared [the San Moisè theatre], and in which these twins were supposed to be presented, is not dissimilar to the one I myself have built [the San Apollinare theatre] in order to cut short the sloth of my financial independence. ${ }^{21}$ [Emphasis added.]

He does not actually claim that he had produced these two works at the San Moisè theatre, but his claim to being enclosed by his debts is similar to all cittadino impresarios of the period. Furthermore, a document (ASV, Archivio notarile, Atti Taddeo Federici, b. 6075, f. 41) (Glixon 1992, 49), suggests that Giovanni Faustini actually signed a three-year agreement with Almorò Zane to mount operas at the San Moisè. Unfortunately, as attested to by this foreword, the agreement was terminated because he was unable to earn suffi-

18Sacrati was probably involved in the production of La finta pazza as well, but Bellerofonte is the first verifiable work for which he acted as impresario at the Novissimo. A letter, cited by Rosand (1991, 106n94), from Matthias de' Medici dated Venice 19 November 1641 , confirms that he was the impresario there at that time.

19 The information about the dismantling of the theatre is provided in Mancini, Muraro, and Povoledo $(1995,1: 323-27)$. Rosand $(1991,88)$ gives evidence of its broad influence: "the Novissimo had a greater impact than any other single theater on the establishment of opera in Venice."

20In his Memorie teatrale di Venezia Cristoforo Ivanovich claims that the music, originally written by Monteverdi, may have been re-written by Francesco Sacrati. Given the fact that Monteverdi was not only still alive, but active, and that he considered Arianna his finest operatic work, this claim is implausible, but Sacrati was heavily involved in opera at this time, and was soon to be the major impresario at Novissimo.

21 Preface to Oristeo, by Giovanni Faustini. Translation by Rosand (1991, 170-71). 
cient funds. Instead, he arranged for the conversion or building of the San Apollinare theatre.

Giovanni Faustini became an impresario at the San Apollinare on May 19, 1650 when he signed a renewable three-year contract with the owners of the property, Zanetta Piamonte (or Diamante) and Francesco and Giovanni Battista Ceroni to produce his opera Oristeo (1651). ${ }^{22} \mathrm{He}$ began work on October 12, 1650 by renovating the theatre, presenting two of his own librettos set by Cavalli, 23 and died suddenly in December, during the mounting of the second opera. ${ }^{24}$ The lawyer Marco Faustini, the most famous impresario in the early years of Venetian commercial opera production, thus entered the impresarial business with the aim of producing all of his brother's incomplete or unperformed operas at the San Apollinare. By 1652, after four financially unsuccessful productions, ${ }^{25}$ he sublet the San Apollinare to Bortolo Castoreo, Annibale Basso, and Paulo Morando, who produced Giacomo Castoreo's Pericle effeminato, composer Francesco Lucio's third opera, in the 1652-53 season, and Pietro Andrea Ziani's La guerriera spartana in 1653-54 season. Marco Faustini returned for the 1654-55 season and produced another of his brother's operas, L'Eupatra as well as two by Aureli. The first, Eupatra, was quite successful, featuring the famous Anna Renzi in the leading role. Over four thousand people saw this work over thirty performances, suggesting that it was more financially successful than any of his previous efforts. ${ }^{26}$ The next work, Erismena, was the most successful opera ever produced at the San Moisè, with 5400 attendees and thirty-two performances (as compared to only ten for Calisto, twenty-three for Eritrea, and thirty for Eupatra). In 1657, after producing L'Eupatra (1654-55) and Le fortune di Rodope (1656-57), Faustini again rented out the San Apollinare to the Accademia degli Imperturbabili and moved his base of operations to the San Cassiano. ${ }^{27}$ In this space, he formed a company with

22 There is some suggestion that he may have managed San Cassiano after Cavalli withdrew in 1644, and he may have had some administrative position at the San Moisè theatre as well, according to Rosand (1991, 170n36).

23 Oristeo and Rosinda.

24 "The lessee commits to doing all the work necessary to equip the space to its new purpose, and may therefore build as many boxes and perform whatever operas in that place as seem appropriate to his whim." ["Il conduttore s'impegnava a fare tutti i lavori necessari per attrezzare l'ambiente alla sua nuova destinazione possendo perciò in quello (loco) far quella quantità di Palchi e far recitar quelle opere che ad esso parerà e piacerà.] (busta 194:179), quoted in Rosand (1991, 170n35), citing Glover $(1975,17-18)$.

25 This period is dealt with in detail with reference to archival documents by B. Glixon and J. Glixon $(1992,48-73)$.

26These numbers are taken from B. Glixon and J. Glixon $(1992,56)$. They compare favourably to the miserable showing for Calisto's ten performances and the mediocre turnout for Eritrea's twenty-two performances. Still it never sold out. Opening night featured over three hundred and twenty but no other night had more than two hundred and fifty, still not a great showing in a house with a capacity of four hundred.

27In the Archivio di Stato, (Scuola Grande di San Marco) busta 133, details of this contract are explained. As B. Glixon and J. Glixon $(1992,70)$ explain, Faustini was unable to collect the rent for this theatre from the literary Academy, the Imperturbabili, and so he changed the locks to prevent their using it in 1658, but in 1659 the problem seems to have been resolved as Faustini allowed their performances to take place. 
Giovanni's old business partners-nobles Marc'Antonio Correr and Alvise Duodo, and the cittadino Polifilo Zuancarli-and signed a renewable five-year contract with Carlo Andrea and Vettor Tron in May 1657 to manage the San Cassiano. 28 "Each member was obliged to pay in an initial capital of 200 ducats per year, and all except Zuancarli were required to make up any further deficit," reported Lorenzo Bianconi and Thomas Walker $(1984,222)$. The first production he mounted at the San Cassiano was $L$ 'incostanza trionfante overo il Teseo (Piccioli et al, P. A. Ziani, 1658), one of the most controversial operas of the period, due to accusations of theft, plagiarism and various other bizarre intrigues. ${ }^{29}$ Bianconi and Walker wrote at length about the next Faustini production, Antioco, in their article, "Production, Consumption and Political Function of Seventeenth-Century Opera" (1984, 209-96), revealing a great deal about the milieu of opera production at this time. Antioco (Minato, Cavalli, 1659) was performed 24 times between January 25 and February 24, 1659. The total cost of the production was $37111,15 \mathrm{Vl}$, including a fee of $18309,6 \mathrm{Vl}$ to the musicians.

Not even the first part of Faustini's renewable five-year contract with the Tron brothers at San Cassiano was fulfilled. In fact, he produced only one more opera there (Elena by Minato/Faustini and Cavalli in 1659-60). Apparently, despite his contract with the Tron brothers, there had been negotiations between Faustini and the Grimanis to take over the running of their theatre, the SS Giovanni e Paolo since 1657 and, some time after July 1658, he annulled the contract with the Trons and signed a new contract with the Grimanis. Faustini's arrival at SS Giovanni e Paolo set in motion twelve consecutive two-opera seasons, (although Faustini was only there for the first seven seasons, 1661-67) creating the first competition with the Vendramin's San Salvatore theatre. Their debut production, Pasife, overo l'impossibile fatto possibile (by Giuseppe Artale, music by Castrovillari, 1661), was an infamous failure, ${ }^{30}$ which was quickly replaced with Faustini/Cavalli's Eritrea.

28 “Gl'Ill.mi NN.HH. Carlo Andrea et Vettor fu del N.H. Franc.co tanto per nome loro proprio quanto per nome del Ill.mo Piero loro fratello absente dalla città ... per ragione di semplice locatione hanno affittato et affittano al Sign. Marco Faustini Avocato ... il Theatro da Comedie di loro ragione detto di S. Cassano con tutte le sue habentie et pertinentie perché quello possa essere da lui ridotto in stato di recitar opere in musica à suo piacimento, come meglio stimerà proprio, potendosi valere di tutto il legname ch'è in opera in detto Theatro; et ciò per anni dieci che principieranno il presente giorno, cioè anni cinque di fermo. Cosicché né i Sigg. Locatori possino escornear esso Faustini, né detto Faustini possi refutar esso Theatro; et altri anni cinque de respetto de anno in anno a piacimento di detto Sign. Conduttore..." Details of the contract between Faustini and the Trons are available in Giazotto (1967, 257).

29 Busta $(188,268)$ in the Archivio di Stato in Venice details the events surrounding this opera. The librettist Francesco Piccioli was unable to assist in the completion or the changes needed for staging of the opera, so other librettists were engaged. The unfortunate composer, P. A. Ziani complained that he had to re-write the opera ten times.

30 In a letter from Giovanni da Mosto to Ottavio Labia (cited in Rosand 1991, 185n65, and in Mangini 1974, 52-53n26), "It was strange that [the opera] at the San Luca, which was no longer able to tolerate the outbursts of the audience who, in an insolence the first evening which was also its last, threw at the stage anything that came to hand, ruining the opera and with shouts and stamping even at $8 o^{\prime}$ clock in the night with greater amusement than ever has been had. The theatre, filled with women, 
Throughout the 1660 s, Faustini had increasingly costly problems with his productions, and in the fall of 1667, a few days after the premiere of Meraspe (text by Giovanni Faustini, music by Pallavicino), he signed over his rights and obligations to the Grimani brothers, and retired, as Cavalli seems to have done before him. Owners of theatres were rarely impresarios in Venetian commercial opera, but Giovanni Carlo and Vincenzo Grimani-who had inherited the SS Giovanni e Paolo theatre in 1663-began running it in 1667. Eleven years later, having experienced some of the success of operatic production, they built the San Giovanni Grisostomo theatre, with a stunning 154 boxes. ${ }^{31}$

Francesco Santurini stands out as the most original impresario in Venetian commercial opera production, because he was the first to understand the need to make opera affordable. Recruited by Marin Zane II (Leclerc 1987, 353), Santurini caused a revolution in the Venetian commercial opera world by lowering the entrance (bollettino) fee from 4 lire to 2 lire, forcing most other theatres to lower their prices as well; only the San Giovanni Grisostomo maintained the higher entrance fee of $4 \mathrm{Vl}$. Santurini's decision was not as egalitarian or altruistic as it may have seemed: the entrance fee, according to Ivanovich (Memorie Teatrali, chap. 14), went to the performers in non-operatic theatre, and if this template was maintained for opera-and it may have been-then this reduction in income did not affect his profit own margin. Faustini's sacrifice would have been on behalf of the performers.

The issue of lowering the price of admission is more complex than it appears though. For example, four lire may have been a reasonable price in 1637 , but the steady increase in the value of the lire made this fee nearly twice as expensive by the 1670s. Lorenzo Bianconi and Thomas Walker cite the pay for various theatrical workers as evidence that four $\mathrm{Vl}$ was a great deal of money at this time. An evening's work earned " $2 \mathrm{Vl}$ for a workman; $0.15 \mathrm{Vl}$ for an extra; 1.10 for the man dressed up as (or providing?) a lion in Act I scene $\mathbf{x x}$ (final scene of the act)" (Bianconi and Walker 1984, 227). The price of a ticket (bollettino) was $4 \mathrm{Vl}$, and the additional price of a scagno (wooden chair) was $1.6 \mathrm{Vl}$ (see appendix 2 for currency values). ${ }^{32}$ The lowering of the entrance fee was extremely successful, as evidenced by the San Moisè and later the Sant' Angelo theatres. ${ }^{33}$ The scagno fee $(1.6 \mathrm{Vl})$, was the fee that Santurini waived, as a means of attracting an audience.

was forced, in order to prevent further unpleasantness, because with one word would have merited worse. Thus was the whole thing replaced by another, which that evening was devised to be performed in that same theatre, and I imagine with similar success." [He writes: "Fu curiosa quela di S. Lucca, che non pottendosi più tolerare proruppe l'auditorio in una insolenza la prima sera, che anco fu l'ultima, gettando in scena tutto quelo veniva alla mani, abbrugiando tutti l'opera et con gridi e batterelle fussimo sino le $\mathbf{8}$ della notte con il maggior solazzo, che mai habbi hautto. Il teatro pieno di dame fu causa che ovviò maggior male, perche in una parola meritavano di peggio. Ghe la mando insieme con un'altra, che questa sera devesi reccitare nel teatro medemo, et stimo con simile aplauso."]

31 According to Giazotto $(1967,266)$, Andrea and Giovanni Carlo were brothers, and the son of Giovanni Carlo, Vincenzo, took over later.

32 Values are provided in Bianconi and Walker (1984, 282, appendix 2). This evidence is confirmed in Papadopoli-Aldobrandini (1907, 3:267-356). In addition, Cipolla's article $(1968,126-45)$ outlines economic reasons for this increase.

33 This translation of chapter 4 of Ivanovich is from Bianconi $(1987,306$, Source Reading 6): "The 
Opera production had become a losing proposition for impresarios, but Santurini found ways to lower his overhead cost to such an extent that he might have earned money had social conditions been more favourable to him. Ivanovich relates Santurini's methods in disparaging tones in chapter 15 of his Memorie Teatrali di Venezia:

The costs of theatre are prescribed, but the profits are determined by the vagaries of fortune. Yet, the theatre's debts increase, for the entrance fees that formed the basis of the investment, rather than growing are diminishing, threatening and endangering the continuation of this noble entertainment. The low price eliminates the possibility of maintaining the considerable cost of splendour, makes entry easier for the ignorant and riotous multitudes, and causes those virtuous works performed as much to delight as for profit to lose their decorum. In the first year that musical dramas appeared in Venice, 1637, the price of a ticket was set at the reasonable sum of four lire, and served as passport to the theatre. This did not change ... until 1674, and ... in that year Francesco Santurini ... violated the integrity of custom by lowering ticket prices to a quarter of a ducat (i.e. less than two lire) at the San Moise theatre. The universal success of this novelty prompted him ... to build the Teatro Sant'Angelo with the help of fees for boxes, and to charge the same admission fee in 1677 .... (Ivanovich 1993, 411-12) 34

Ivanovich had a hidden agenda in making his criticism; the book in which he wrote this was dedicated to Giovanni Carlo and Vincenzo Grimani, proprietors of the S. Giovanni Grisostomo theatre, and more importantly, two of his operas, La costanza trionfante (San Moisè, 1673) and La Circe (Sant' Angelo, 1679)

principal difference is that the theatres of today, in comparison with those of the ancients, have room for only a limited number of persons; moreover, instead of stepwise tiers of seats, they are constructed with several tiers of boxes, mostly reserved for the convenience of the nobles, where the ladies can also remain in total liberty without masks. In the middle section [i.e., the stalls], the benches are rented out on a day-to-day basis without social distinction, since the use of masks obviated the necessity of former times for the observance of respect on the presence of the grandiose matrons and senators of Rome (the free-born republic of Venice embracing, as it does, a desire to preserve the freedom of all). Nor is the magnificence of one to be compared with the other since Rome lavished great fortunes on its theatrical productions-once considered among its greatest splendours-and its machines were the wonder of the world."

34 "Le spese del Teatro sono più che certe; ma gli utiliderivando, come s'è detto, dagli scherzi di fortuna sono incerti. Pure il Teatro studia sempre più d'accrescer i suoi aggravij; ma l'utile della Porta, ch'è fondamento principale dell'interesse, in vece di crescere si và diminuendo con evidente pregiudizio, e pericolo di tralasciarsi la continuazione di questo nobilissimo trattenimento. Il poco prezzo lieva il modo alla spesa considerabile delle pompe, introduce più facilmente il Volgo ignorante, e tumultuario, e fà perder il decoro à quella Virtù, che comparisce non meno der diletto, che per profitto. L'anno primo, che comparì in Venezia il Drama in Musica fù del 1637 si limitò come onesta contribuzione il pagamento di lire quattro per bollettino, che serve di passaporta nel Teatro. Durò l'uso della medema inalterabile ... fino l'anno 1674 e ... Francesco Santurini quell'anno col comodo del Teatro di San Moisè ... non violava l'integrità dell'uso sudetto, con un quarto di ducato alla Porta. Questa novità vantaggiosa piacque all'universale ... e gli sorti di fabricar il Teatro di Sant'Angelo, col beneficio del regalo di Palchetti, ed aprirlo col prezzo medemo alla Porta l'anno 1677...." 
had been produced by Santurini. Ivanovich may have been unhappy with the parsimonious productions Santurini gave his work.

When Santurini took it over in 1672, the San Moisè was very small by Venetian standards, with five rows of twenty-nine boxes (145 in total) and about 500 seats. It had not been used for theatre since 1666, but a loan of sets and materials allowed Santurini to create an opera for a relatively low price in Carnevale of 1673 (Ivanovich 1993, 411-12). ${ }^{35}$ Unfortunately for Ivanovich, the pinchpenny work happened to be his (and Partenio's) La costanza trionfante. ${ }^{36}$ This and the following Santurini operas caused a sensation in Venice as we can see in this letter sent to the Duke of Hanover:

The Grimani Theatre [SS Giovanni e Paolo] did not get applause for much other than Signora Giulia, and for the scenery, the victory went to the San Luca [San Salvatore theatre], although neither had much to recommend them, for they lacked the two mainstays of the previous year; Lucretia and the castrato Lassi. San Moisè also had musical productions, and one did not pay at the door, but purchased tickets beforehand; those who had their own box did not have to pay to enter, and were given four tickets to allow four of their friends to come in to their box for free. Those who did not have boxes, purchased tickets and rented a box if they wanted one. ${ }^{37}$

The box fee, then, is paid only if more than four people are in attendance, as this other letter from Dolfin demonstrates:

Again, at San Moisè, an opera is running with no other price than that of the box, but it is so good that many are paying to return there more than once, and it has a lot of applause and is always full. ${ }^{38}$

35 “... se Francesco Santurini quell'anno col comodo del Teatro di San Moisè preso ad affitto vantaggiosamente, con le Scene, e Materiali, che servirono l'anno innanzi ad una generosità Accademica, e con una mediocre compagnia de' Cantanti non violava l'integrità dell'uso sudetto, con un quarto di ducato alla Porta."

36Further Santurini productions included La schiava fortunata (Moniglia/Corradi, music by M. A. Ziani) in the 1673-74 season, L'Almerico in Cipro (Girolamo Castelli, music by Antonio dal Gaudio) in the 1674-75 season, and two works, Medea in Atene (Aureli and Antonio Zanettini) and Leonida in Tegea (Minato, music by Draghi and M. A. Ziani) in the 1675-76 season, and a further two in the 1676-77 season, Giocasta regina d'Armenia (Moniglia, music by Castoreo/C. Grossi) and Il Nicomede in Bitinia (Giannini, Grossi).

37Translation mine, taken from a letter from Massi to the Duke of Brunswick, 30 December 1672 from Hanover, Staatsarchiv: Aktes-Korrespondenzen italienischer Kardinäle und anderer Personen, besonders Italiener an Herzog Johann Friedrich (4, no. 627, f 266v), quoted (but not translated) in Rosand $(1991,442)$ : "Il Teatro Grimano non riesce con applauso per altro rispetto che Sig. Giulia, e per le scene, lo vince quello di San Luca, ne l'uno ne l'altro molto a proposito, perche mancano le due colonette dell'anno passato; la Sigra Lucretia, et il castratino Lassi. Anco a San Moise si fa opera in musica, e non si fa pagare alle porte, ma dispensano bollettini; chi ha palco proprio, non paga manco all'entrare, et è accomodato di quattro bollettini per goder nel suo palco quattro amici cosi gratis; e quelli che non hanno il palco pagano li bollettini, et il palco se lo vogliono."

38 Letter from Dolfin to the Duke of Brunswick, 20 January $1673(2$, no. 625, 440 -41$)$, quoted in Rosand (1991, 443): “Anco à S. Moisè si fa un opera, senz'altra spesa che quella del Palco, mà è tanto 
When the Sant' Angelo theatre opened in 1677, the year before the San Giovanni Grisostomo, there was a great deal of hope for Venetian theatre; competition was fierce and works were being premiered at an unprecedented rate. Santurini built the Sant'Angelo on land owned by the great noble families of Marcello and Capello, signed the contract on August 15, 1676, and opened for Carnevale 1677 with a successful production of Aureli/Freschi's Elena rapita da Paride. ${ }^{39}$ His contract with the landowners stipulated that he build the theatre with his own money (or, more accurately, with money he had raised by pre-selling the boxes) and pay them 30 ducats per year, as well as 100 ducats deposit, to be returned at the end of the contract. At the end of this seven-year contract, the whole property would revert to the ownership of the "Nobil Homeni e Nobil Donne Capello e Marcello." 40 Santurini was probably aware that he was fighting a losing battle, being a popolano in competition with the noble Zane, Tron, Vendramin and Grimani families, who had much more wealth and status at their disposal, but he continued in business until the end of the contract, relying on inexpensive sets and an apparently mediocre company. Unfortunately for Santurini, the Venetian impresario had been in a difficult position since the beginning of commercial opera: while he could think of the rents owed to him as credits, he needed cash to pay some creditors, or he would be forced into bankruptcy. He had tried to use the boxes to pay off some creditors, but his inability to exact payment from a large number of nobles (Barbarigo, Venier, Pisani, Bembo, Mocenigo, Correr and others) ${ }^{41}$ eventually put him in an economically unsustainable position. His social position did not enable him to recoup this money despite the many legal rulings stipulating that he must be paid. As a result of this, he was also unable to defend himself against the suit filed by the Capello and Marcello families and, in 1683, Santurini, with his unrecoverable "credit", was forced to beg for an extension of his contract. He was given a two-year reprieve by the Marcello (excepting Giacomo Antonio Marcello $)^{42}$ and Capello families, during which he tried to recover all the money owed to him, but despite his court victories, he failed and was forced out of business in 1685 .

poco di buono, che più d'una volta non torna il copnto di vederla, e pur questa hà l'applauso, et è sempre ripieno il Teatro."

39 The property was in the parish of San Angelo, on the corte dell'Albero, overlooking the Grand Canal. The land, according to Nicola Mangini $(1974,43)$, was for the most part ruined, having been disused for a long time.

40 The contract is reproduced in Mangini (1974, 73-76).

41 Giazotto $(1967,262)$ records the lawsuits concerning rent of boxes (and theatres) by the Grimani between 1658 and 1700. They include Polo Boldù, Nicolò Contarini, Vettor Contarini, N. H. Donini, Domenico Correr, Francesco and Giovanni Tron, Francesco Vidman, Antonio Pisani, Ascanio Giustinian, Bortolo Querini, Alvise Mocenigo, Alessandro Molin, Piero Valiero, Cecilia Badoar, the Bellotto sisters, Ferigo Gradenigo, Sebastiano Foscarini, Costantino Priuli, Girolamo Mocenigo, Andrea Capello, Filippo Bon, Giacomo Cana, and many others. Many of these were not settled, and the Grimani had considerable influence in Venice, whereas Santurini, who would probably have had a similar list of deadbeats, did not.

42Referred to by Giazzotto $(1967,482-84)$ as coming from Notarile, Atti Bronzini. B. 1316, cc. 142 e $143.1683,2$ e 4 ottobre. 
The Grimani family fared better than Santurini. By 1683, they controlled the San Samuele, the SS Giovanni e Paolo, the San Giovanni Grisostomo and the San Salvatore theatre (although this theatre was still owned by the Vendramin family), giving them a near monopoly over Venetian theatres. ${ }^{43} \mathrm{Al}$ though the original family association with opera was from Giovanni Grimani (d. 1663), who had established the San Samuele, a commedia dell'arte theatre, in 1655-56 as well as the SS Giovanni e Paolo, the Grimani's monopoly in Venice became clear only in the $1680 \mathrm{~s}$, when Giovanni Carlo and Vincenzo had consolidated their control over Venetian opera. Highly placed in Venetian society, their indisputable social standing gave them an insurmountable advantage over non-noble impresarios in procuring the finest performers, composers and librettists. ${ }^{44}$

By 1678 , both Grimani brothers were experienced in theatre, but both were under 30. Until 1677, the San Salvatore (a Vendramin theatre) had been their only major competition. They were in the very advantageous position of owning and operating their theatres, the SS Giovanni e Paolo and later the San Giovanni Grisostomo. At the latter opera house, both of them tried their hand at writing librettos as well..$^{45}$

\section{The TARget AudienCe}

Almost every opera theatre in Venice held at least five hundred people, and most operas in the early years held between twelve and forty performances of any given production. ${ }^{46}$ If we can consider a successful production to have sold one half of the seats during its run, then a minimum of 3,000 and up to 20,000 people would have seen a successful opera. In 1630, Venice was a city of between 140,000 and 160,000 residents, but the plague of 1629-30 killed 30 percent of the population. By 1640 , immigration had increased the resident population back to 120,000 . There was a significant non-resident (i.e. temporary foreign residents, tourists, diplomats, merchants, etc.) population in Venice, more than in any other European city, and a large number of these non-residents were wealthy diplomats and business people. It was also the first

43 The San Salvatore theatre came under the control of the Grimani family in 1683 when they forced Gaspare Torelli who held the lease for the theatre to cede it to them as subtenants for the length of his contract. Mancini, Muraro, and Povoledo (1995, 1:214-15), explain that it returned to Vendramin control in 1689.

44 According to Saunders $(1985,4-7)$, the Grimani brothers' mother was the daughter of Luigi Francesco Gonzaga, the Marquis of Palazzolo, related to the Duke of Mantua. Giovanni Carlo (1648-1714) married into the three Venetian noble families, the Pisani (his first wife), Manin (his second wife) and Foscarini (his third wife), assuring himself a place in society. His brother, Vincenzo was involved in the clergy and had allied himself in diplomatic circles with the House of Savoy and the Emperor Leopold I. In 1677, the Duke of Mantua granted him the lucrative abbey of Lucedio in Monferrato, and Emperor Leopold recommended him to the "purple" in 1697, serving as the Emperor's principle representative in Rome during the War of the Spanish Succession. He was appointed Viceroy of Naples in 1708 (where he died in 1710). The Grimani brothers were first cousins and the closest living relatives to the Doge Alvise II Mocinego (1700-1709).

45For more information on the San Giovanni Grisostomo Theatre, please see Saunders (1985).

46 A great deal of information relating to the theatres can be found in Mancini, Muraro, and Povoleda (1995). 
city in Europe to which thousands of English, French, German and Dutch non-religious pilgrims would flock every year, many of whom were extremely wealthy and influential. The city, unlike the popular Christian pilgrimage sites, was more of a tourist destination-it was the highlight of the popular English tradition of the Grand Tour-and it had a risque reputation that the city strove to maintain. Commedia dell'arte, the indigenous improvisatory theatre, had been popular for over a century, and the Early Modern masterpieces of Italian art, Byzantine treasures and architecture, combined with business opportunities, an energetic diplomatic community and outdoor festivals to create a mystique that was genuinely separate from religion. Opera was sufficiently highbrow, but simultaneously titillating - women were performing on stage, courtesans were in attendance, the wearing of masks ensured anonymity-to make it the perfect addition to this carefully constructed adult playground.

The identity of opera patrons is difficult to discover because although there are several extant lists of box-holders, there are none that list the names of all the spectators. Nevertheless, I have made attempts to describe a typical Venetian audience. For the second half of the seventeenth-century (at least), the bulk of the public for Venetian opera could be divided into three social classes: The Nobili-wealthy Venetian patricians; the numerous foreign officials and foreign princes; and the citizens (cittadino) of Venice. ${ }^{47}$ Gondoliers, who might have enjoyed the opera "had free right of entry to the opera-house and acted as its claque" (Wolff 1975, 11).48

The Calendar of State Papers cites an English resident who complained to the government that his box had not been awarded to him. This note also mentions that "he did not care for music, esteem poetry or understand the stage, but merely desired it for the honour of his office, as his predecessor and all the other residents at present at the court enjoy the favour." 49 The Doge himself allotted boxes to the heads of foreign missions and, according to a report in the Venetian State Archives, when requested, he drew lots for boxes in each theatre except stage boxes, those already held by diplomats, and the one belonging to the minister's immediate predecessor. If the head of the foreign mission did

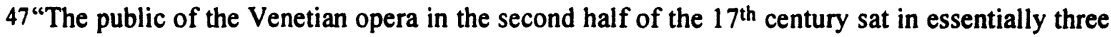
distinct classes. Of the nobles, the wealthy Venetian merchants, then the numerous foreign officials and princes together with their adherents, and finally the middle-class Venetians. The nobles (Nobili) were, in fact what made the building of the numerous opera theatres possible at this time. Because they purchased these theatrical boxes often before the theatre was built, a Nobile provided a significant amount of the initial investment in the theatre." (Wolff 1975, 17) ["Das Publikum der Venezianischen Oper in der zweiten Hălfte des 17. Jahrhunderts setze sich im Wesentlichen aus drei Gesellschaftsklassen zusammen. Aus den „Nobili“, den reichen venezianischen Kaufleuten, dann den zahlreichen ausländischen Gesandten und Fürsten nebst deren Anhang, und schliesslich den kleineren Bürgern Venedigs. Die „Nobili“" waren es eigentlich, welche die Errichtung der zahlreichen Operntheater in dieser Zeit überhaupt ermöglichten. Denn sie kauften, noch bevor das Theater erbaut war, bei einem Theaterunternehmer, meist ebenfalls einem „Nobile“, eine Loge und zahlten fur diese eine ansehnliche Summe.”] 48 Also in Mamy (1996, 87): "Les gondoliers, quant à eux, entrent librement dans les théâtres de Venise."

49 Calendar of State Papers, Venice $(1671-72,152)$, cited in and translated by Worsthorne (1954, 12n1). 
not like the box he was allotted, "a further draw could be made, but the proprietor of the original always lost his box. The owner of the box concerned in the second draw moved into that drawn originally. In this way there could be no hint of collusion between a Venetian and the minister." 50 The rest of the boxes were occupied by members of the Venetian patrician class.

A word should be said about the nature of the Nobili of Venice, because they were not like the nobility in other European states. They were taken from a relatively broad cross-section of society (about $4 \%$ of the total population in the seventeenth-century), including wealthy merchants and ancient families; they were involved in the running of Venice because of the oligarchic style of governance; they were not necessarily wealthy. Although there had been a large number of Nobili in the 1500 s, between 1550 and 1594 the number of male nobles had been reduced from about 2,500 to fewer than 2,000. After the great plague of 1629-30, there were only 1,666, and they did not increase in number until the eighteenth century, even though between 1647-69, there began an effort to augment their numbers by adding eighty new families to their ranks, by charging 100,000 ducats for a title in a bid to provide funds for the War of Candia. ${ }^{51}$

Ellen Rosand $(1991,2)$ describes the list of subscribers to the opera in any theatre at the time a "a who's-who of Venetian society" (Rosand 1991, 2). The term "subscribers," in this context, refers to those who paid the annual lease on the boxes rather than the entire audience (i.e. excluding those who sat in the parterre, which was unusually diverse). ${ }^{52}$ If the occupants of the boxes were largely diplomats and Venetian noblemen, and Venetian noblemen were often involved in government, it would seem that opera had - at least obliquely-an important role in the diplomatic, political and economic relations of Venice. As with most other aspects of life in Venice, Venetians and diplomats stationed in Venice considered attendance at operas slightly morally suspect yet important for their social standing. Because of this, the Venetian secret police, the Inquisitori di Stato considered operas to be important, and maintained copious notes on who attended. They considered this information important because interacting with foreigners was suspicious behaviour in Venice. The trouble with both of these sources is that they are slanted toward the wealthy and

50Reproduced and translated by Worsthorne $(1954,12)$ from Busta 914 (Inquisitore di Stato, Ambasciatore stere [sic]) in the Archivio del Stato. The original reads: "Metodo che si tiene dai Ministri per recercare li Palchi: Si presentano con Memoriale come dagli uniti Esemplari, all' Ecc ${ }^{\text {ma }}$ Consulta. Da questa col mezzo d'un Secretario de Senato viene ricercato il Serenissimo di far l'estrazione delli Palchi respettivi. Egli imbossolando tutti li Palchi di quell' Ordine ch'è relattivo al carattere di quel Ministro che lo ricerca, fà l'estrazione di uno a sorte Si eccetriano li Procennii ed il Pargoletto li Palchi tenuti dagl' altri Ministri e quello ch'era tenuto dal Ministro ultimamente partito. Poi col metodo che s'indicherà qui avanti se ne avvanza l'avviso tanto al Ministro, che al Proprietario ed alla Consulta.

"Quando il Palco estratto non accomoda a quel Ministro, egli avanza le sue ricerche alla Consulta perchè gli venga cambiato e con lo stesso metodo viene ricercato il Serenissimo d'una nuova estrazione. Egli in tal caso imbossolando solo i palchi in faccia liberi, fà una nuova estrazione e avvanza gli avvisi correspondenti, avvertendo il Proprietario del Secondo Palco, ch'egli avrà il godimento dell' altro Palco, che dapprima estratto."

51 Statistics taken from Lane $(1973,430)$.

52 This is the assessment of Mangini $(1974,38)$, citing Petrobelli $(1965,3: 128,38)$. 
influential, tending to ignore the middle class merchants, who had neither the motivation nor the inclination to engage in high-level talks that would affect the state's affairs. The amount of financial influence wielded by the 2-lire-paying public is negligible though, and so a lack of information about them is not as damaging as one might think. ${ }^{53}$

\section{FinanCial ORganization OF THE Theatres: SOURCES OF INCOME}

Cristoforo Ivanovich, author of Memorie teatrali di Venezia (1688) describes how theatre companies were organized in such a way that various sources of income went to various groups and individuals. As he describes it, profits from the theatrical boxes (palchetti) went mainly to the impresario with a certain number reserved for the owner. The entrance fees (bollettini), the seat fees (scagni), and the refreshment stall income (botteghini) were divided up in this way:

The final use is taken from the rent from the boxes, which, since their number can exceed one hundred, can be considerable; and despite the quality of the drama, this is always the same, as long as there is a production each Carnival season. The other income taken from Comedy theatre may consist of the rents from the boxes. Whereas every other income is for the players, including an honorarium from the income earned by the proprietor of the theatre from the box rentals. (Ivanovich 1993, chap. 14) ${ }^{54}$

If we can presume that this organization was not significantly different for operatic productions, then the pay for the performers (including the composer, who was generally the leader of the orchestra), ${ }^{55}$ would fluctuate according to how much was taken in the bollettino entrance fee. Librettists had an even more arm's-length relationship with the opera; they were generally unpaid by theatre managers. Instead, they were given exclusive rights to print and sell their librettos, which meant that their financial success was indirectly tied to the success of the opera, but not necessarily to the financial success of that particular performance. Librettos were frequently dedicated to an aristocrat who paid for this privilege; the librettist would then have it printed, and would keep all the profits from its sales. Librettos were often sold during the perform-

53Bianconi $(1987,184)$ writes: "the widespread idea of the 'popularity' of Venetian opera as opposed to the aristocratic pretensions of court opera can no longer be sustained; available documentation on audience composition clearly shows the irrelevance of lower-class opera-goers for the economic structure of the theatre."

54 Translation mine. Ivanovich's original, from chapter 14, reads: "l'ultimo utile, che si ricava si e quello degli affitti de'Palchetti, che per esser in numero quasi di cento, diviene considerabile; e questo ò riesca, ò non il Drama, sempre è lo stesso, nè può mancare annualmente ogni volta, che recita il Teatro in quel Carnovale. L'utile poi, che si cava dal Teatro della Comedia, consiste negli affitti de'Palchetti; mentre ogni altro utile è de'Comici; a'quali è tenuto il Padrone del Teatro à far'un regalo di quello, che si cava da essi Palchetti."

55 The only exceptions to this rule are when the work is a revival of a previous work. In these cases, the music was either used or adapted, probably without recompense to the original composer, or else a new score was composed, and the new composer led the orchestra. 
ance along with a candle, used to read it while the lights were turned low. Thus, the librettist's financial involvement in the actual production of the opera was somewhat more arm's length than the other participants. The owner of the theatre received a rental fee from the theatre manager (impresario), and stood to gain every season his theatre was rented, independent of the success or number of productions. His only risk was the (admittedly high) risk of fire. The San Cassiano theatre burned in 1618-19, and again in 1629, (it was rebuilt in 1637); the San Salvatore was built over a ruined theatre in 1622 and burned in 1660 , prompting the Vendramin family to renovate it into an opera theatre. Even the great SS Giovanni e Paolo burned to the ground in 1748; in 1678, the San Moisè burned out and was rebuilt several years later as a puppet theatre. Nevertheless, the social advantage of being a theatre owner was significant in a city whose primary attraction was the opera. Providing one could afford the initial outlay of funds, theatre ownership was the safest way to profit from the opera.

The very first production, Andromeda, was quite likely inexpensive to mount. All the members of the company, organized as a sort of co-operative, were multi-tasking and assuming some of the considerable financial risk. Nevertheless, La maga fulminata, their next production was mounted for two thousand scudi, according to the preface to the libretto (see footnote 12). Ellen Rosand points out that the price of producing opera began to rise quickly. For example:

in 1669 the total cost of a production at S. Salvatore was 62,966 Venetian lire, nearly twice that of Antioco at S. Cassiano ten years earlier, which in turn was twice that of the second production at S. Cassiano in 1638, where a small company of six, including the composer, librettist, and singers, all serving multiple functions, shouldered the entire responsibility of presenting La maga fulminata for 2,000 scudi (or 19,200 Venetian lire) (Rosand 1991, 196).

The cost for the opera at San Salvatore comes from a sheet of accounts in I-Vcg, Archivio Vendramin, Teatro S. Salvatore, b. 42 F 6/I-6 [49], no. 20, 13 April 1669.56

In order for the cost of production to skyrocket, though, fundraising had to increase concomitantly. Box fees were a safe source of income, being more or less independent of the quality of the show, and so quickly became the major source of income for Venetian operas. A theatrical box was considered an essential part of a good Venetian family's assets, as Ivanovich (1993) describes in chapter 10:

The leasing of the boxes provides the most secure income of every theatre. There are at least one hundred of these, besides the various orders of galleries [boxes at the attic level]; ${ }^{57}$ not all are equal in price, the latter being calculated on the basis of the order and number (i.e. the excellence of position) of each

56 A copy of this is available in Rosand $(1991,197)$.

57 This is a correction of the misreading in Bianconi. 
box ... From the very beginning, theatre proprietors have customarily practised two types of charges: first, a cash payment for each box (this serves largely to cover construction costs, and is the principal reason for the ease and rapidity with which the construction of a number of theatres has been possible); second, an agreed annual rent paid every year in which there is an opera season (only in this way does the said payment correspond both to the expenses incurred by the theatre and the comfort and convenience enjoyed by the box). The right acquired by the possessor of the box is that of retaining it on his account, without the option of re-letting it to others; he may make use of it for his own purposes and lend it out, as he likes ... There are also various boxes at ground level and gallery level, which, by virtue of their inferior or inconvenient position, are not all rented out at the beginning, but rather on a nightly or annual basis at the free discretion of the theatre proprietor, who thus attempts to procure for himself the greatest possible advantage. ${ }^{58}$

The box seat then, was financed by a wealthy family or individual who was assured the right of first refusal of this particular box every year, while also committing to an annual payment for the upkeep of the public part of the theatre, and some of the costs of production. This method continues to be a system used for box seating at sporting events in major stadiums throughout North America, and in Italy and much of the rest of Europe for buying box seats at the opera. Unfortunately, exactly when this practice began is unclear, because the very existence of boxes in the early years is in doubt. Nino Pirrotta $(1984,263-66)^{59}$ questioned the accepted view that Venetian theatre design was influenced in all cases by the Teatro Farnese in Padua, in which there were:

five rows of galleries circled all around, one above the other, with parapets of marble balusters; the spaces, large enough to accommodate sixteen spectators each ... separated by partitions ... The two highest and most distant rows were filled with common citizens; on the third sat the students and foreign nobility; the second, as the more worthy place, was for the rectors and the Venetian noblemen; and in the first there were the gentlewomen and the principal gentlemen of the court." 60

He suggested that theatrical boxes may not have been introduced at the San Moisè theatre until 1688, which means that Santurini would have had no access to them. If Pirrotta's claim was accurate, and there were no boxes at the San Moise until 1688, then this would have been a great incentive for him to build the Sant'Angelo theatre. He cites two pieces of evidence in the prologue to Sidonio e Dorisbe, performed in 1642 at San Moisè, in which the theatre is described as a "narrow and poorly decorated room," and a stage direction that

58Translation from Bianconi $(1987,308)$.

59 Pirrotta's view is not generally accepted by other scholars either.

60From L'ERMIONA del S. Marchese Pio Enea Obizzi Per introduzione d'un Torneo à piedi \& $a$ cavalli E d'un Balletto rappresentato in Musica nella Città di Padova l'Anno M.DC.XXXVI dedicata Al Sereniss. Principe di Venetia FRANCESCO ERIZO descritta dal S.Nicolo Enea Bartolini Gentil-

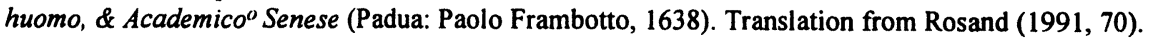


indicates that "Tempo, a character in the prologue, is to take a place near some ladies, whose gambling he has interrupted" (Rosand 1991, 80n41). While this evidence is not entirely conclusive, it does throw into question whether box fundraising began with the first commercial opera productions. In any case, once there were boxes, there was a demand for the income from them from the beginning of this practice.

The Teatro SS Giovanni e Paolo is believed to have had seventy-seven boxes in four rows from the 1630s until the 1660s when the boxes were re-arranged into five rows of twenty-nine, or 145 (Mancini, Murara, and Povoledo 1996, 1:294). By the 1670s, according to Le Mercure galant newspaper, the theatre boasted five rows with thirty-two boxes each, or 160 boxes. In 1657, when the company headed by Marco Faustini was producing opera (1650-57), the Teatro San Apollinare had three rows of fifteen or sixteen boxes, making forty-eight boxes, renting for twenty ducats per year. An income of 960 ducats from this single source is particularly impressive because Giovanni Faustini had initially rented the San Apollinare theatre for only 60 ducats per year for three years (with an extension of an additional three years), on condition that he turn it into a theatre. ${ }^{61}$ In 1657, the company moved, lock, stock and barrel, to the San Cassiano theatre, where there were ninety-eight boxes which rented for twentyfive ducats a year (this information is only available for later years, so there may have been fewer boxes in 1657). Faustini apparently took many of the moveable items (sets, lights, seating and so forth) from San Apollinare with him to San Cassiano, but Bianconi and Walker imply that the profits from the box rentals at the San Cassiano were eroded by the obligation to ready the theatre for performance, which involved a significant expense. Owned by the Tron brothers, it was leased to (only) Marco Faustini for five years, at eight hundred ducats per year, plus forty ducats for a storage house near the theatre. Faustini was the proprietor of ninety-two of the ninety-eight boxes (the remaining six were reserved by the Tron family). He rented these boxes for twentyfive ducats per year in 1657, using the profits to renovate the theatre. In 1666, the next year for which there are figures available, the boxes rented, again, for twenty-five ducats per year (appendix 1).

In the Venetian economic model for operas, the impresario assumed the largest financial risk. According to Bianconi $(1987,183)$ : "advance letting of boxes for the entire season provide[d] a sizeable portion of the liquid capital required for investment in the operatic productions themselves." The entrance fee (bollettino) to the theatre until 1674 was two lire. In chapter 13, Ivanovich outlines the expenses "il Teatro" (the impresario) had to pay. These include the singers (the largest amount), the composer, the choreographer, instrumentalists and theatrical hands, whose fees were ideally covered by the bollettini; costumes, mutazioni di scena, machine construction and lighting, whose fees

61 "Il conduttore s'impegnava a fare tutti i lavori necessari per attrezzare l'ambiente alla sua nuova destinazione possendo perciò in quello [loco] far quella quantità di Palchi e far recitar quelle opere che ad esso parerà e piacerà" (busta 194, 179), quoted in Glover (1975, 17-18). 
were deducted from the annual box fees, seat (scagno) fees, and botteghini income.

\section{Librettos AND Scenarios as PUblicity ITEMS}

Given the fact that opera in the seventeenth-century had no single economic plan, it came to exist based on several different, often conflicting models, some artistic and others commercial. There is some question as to whether those involved in Venetian opera of the 1630s and 1640s even knew about the Florentine, Roman or Mantuan courtly opera experiments (other than Monteverdi, who obviously must have), but the courtly opera model was obviously used for at least some elements of the operatic business design. For example, Monteverdi/Striggio's Orfeo of 1607 had a printed libretto that was handed out to the guests as a sort of souvenir of the event. For the first two commercial operas, Andromeda and La maga fulminata souvenir librettos were published (by Antonio Bariletti in May 6, 1637, several months after it had closed in the case of Andromeda, and by Ferrari on February 6, 1638, while it was still running, in the case of La maga fulminata), despite the fact that there was no immediately apparent publicity reason to publish a libretto after an opera had closed, at least none that would benefit the production. That is, it could not attract an audience to see the show if it was closed. In the case of Andromeda, at least, this was the case. The scenario to La maga fulminata is less clearly inspired by the earlier courtly operas, because the libretto was made available before the opera closed, suggesting that it might have been sold during the performance, to be read during the show. ${ }^{62}$

The existence of the libretto sold for use during a performance is significant, because it suggests that there may have been some resistance to this artistic hybrid of music and drama, and that the printed libretto, used in a similar fashion to surtitles today, was offered as a means of bridging this divide for audiences. It is well known that words combined with music are less well understood as narrative than words on their own, and the plot was clearly important to the impresarios, since composers were not treated with the same respect as librettists. Composers were artisans while librettists, especially in the early years of opera production in Venice, were nobles, aristocrats or at least upper middle class scholars, often associated with influential accademias like the Incogniti, Instabile or the Imperfetti, while musicians were either self-supporting or associated with the church. ${ }^{63}$

62Per Bjurström $(1961,44 \mathrm{n} 22)$ points out that librettos were printed for a large number of these courtly spectacles, including G. B. Estense Tassone's La Contessa (Ferrara, 1632), Rospigliosi's Erminia sul Giordano (Rome, 1637), A. Pio di Savoia's La Discordia superata (Ferrara, 1635) and Andromeda (Ferrara, 1638).

63Librettists who were associated with the Accademia degli Incogniti include Giulio Strozzi ( $L a$ finta pazza), Francesco Busenello (L'incoronazione di Poppea), Paolo Vendramin (L'Adone), Giovanni Francesco Loredan (co-author of Amore innamorato), Pietro Michiel, (co-author of Amore innamorato), Vincenzo Nolfi (Bellerofonte), Maiolino Bisaccioni (Ercole in Lidia), Giacomo Badoaro (Il ritorno d'Ulisse in Patria), Marc'Antonio Tirabosco (L'Alcate), Niccolò Enea Bartolini, Scipione Herrico (Deidamia), Pietro Paolo Bissari (Bradamante). Busenello, Aureliano Aureli, Nicolò Minato, Giacomo 
Librettists had access to a relatively inexpensive method of duplicating their creations that allowed them to sell them (or rather reproductions of them) for profit. Willem Janszoon Blaeu's 1620 improvement to the printing press (a counterweight to the platen or metal print plate) reduced the work needed to operate the machine by half, making printing suddenly much more financially feasible for publicity purposes. With this increase in the speed of printing came an increase in printed material, which in turn created an increased number of people who could read. Venice had been the world leader in printing since the beginning of the sixteenth century and was well positioned to take advantage of this increase in the literacy rate. ${ }^{64}$ It was fertile ground for Benedetto Ferrari and Francesco Manelli to produce their opera, Andromeda, at the newly refurbished San Cassiano theatre in Venice. It was neither Ferrari nor Manelli however, but the publisher Antonio Bariletti who first created publicity materials with the help of the city's forty or fifty printing presses; his "spin" took the form of published librettos, and shortly others introduced a new type of publication called a scenario. ${ }^{65}$ The Venetian libretto is a substantial publication that includes not only the full text of the opera, but also other important information deemed important by the librettist. A scenario, on the other hand is usually one duodecimo fascicle (i.e. twenty-four pages), with a synopsis and some information to tell the reader the location and time of the performance. It is, in short, a publicity document, similar in style to a playbill for a modern opera (except that it was handed out to encourage people to go to the opera and not once they were already there).${ }^{66} \mathrm{It}$ is not difficult to imagine that this libretto earned a substantial profit, particularly if it were sold along with a candle so that it could be read during the performance. In the absence of documentary evidence of the reaction to this innovation, it is unclear whether this publication

Dall' Angelo were associated with the Accademia degli Imperfetti, while Giacinto Andrea Cicognini was in the Accademia dei Instabile. Cristoforo Ivanovich was associated with the Accademia dei Concordi as well as San Marco, and Giovanni Faustini seems to have been the only librettist who can be shown to have earned his living by writing. On the other hand, the number of musicians who were employed by San Marco is nearly as many: composers associated with San Marco were Francesco Manelli (singer 1639-45), Francesco Cavalli (maestro di cappella), Claudio Monteverdi (maestro di cappella), Giovanni Rovetta (maestro di cappella), Antonio Sartorio (vice-maestro di cappella), Pietro Andrea Ziani (organist 1669-73), Legrenzi (vice-maestro di cappella). Benedetto Ferrari was an independent musician, librettist and impresario employed in various courts in Parma, Modena and Rome throughout his career, while Francesco Sacrati, from Parma, was an independent musician and an impresario, and Antonio Cesti was a priest until 1659, and a famous singer. There is no record of an opera composer being a member of an accademia until the eighteenth century.

64 Several factors contributed to the existence of such a large number of printing presses in Venice. These included access to large amounts of good quality paper from the Riviera di Salo on Lake Garda, the enlightened governmental policy toward the printing trade, and the immense manuscript resources available in Venice both at the state collection that came to be known as the Biblioteca marciana, and in the numerous private collections owned by Venetian nobles.

65 By 1490, there were more than 150 presses in Venice as compared to 60 in Milan, 42 in Bologna, 37 in Rome and 22 in Florence, but after 1490, printers began moving away. By 1630 there were only about 40 printers left in Venice, as the industry had moved to the Low Countries, according to Logan $(1972,74)$.

66 The following information about scenarios and librettos is substantially taken from Rosand (1991, 81-88). 
was the catalyst for the explosion in the number of opera productions in Venice, or a result of their success.

Giulio Strozzi was the first to use the scenario as a publicity tool for his production, La Delia. Strozzi recognized the importance of providing the public with advance publicity in order to make his work a critical and financial success (Rosand 1991, 85). Using various lures, including the fame of its composer, Francesco Manelli, who had written music for Andromeda, and the fact that it was the inaugural opera for the new theatre SS Giovanni e Paolo, Strozzi published his scenario over a month before the opera opened. A thirty-three-page volume on low-quality paper, clearly designed as a disposable document, La Delia's scenario consisted of a synopsis and a running description of the action, a preface by the author, and even an advertisement for the next production, Ferrari's Armida.

The next scenario that appeared in Venice was printed only two months later, by Strozzi's competition. Francesco Cavalli's new company at the San Cassiano theatre seems to have imitated Giulio Strozzi's method for La Delia producing a similar, but less effective scenario for their opera, Le nozze di Teti e di Peleo (by Orazio Persiani and Cavalli). Although it provides important information such as the name of the venue, the composer, and some information about the performers, it does not boast about the opera's qualities nearly the way Strozzi's does. Nevertheless, for the next few years, the scenario was a major form of publicity for Venetian opera. Other opera productions that used scenarios include the most performed opera of the century, Strozzi's La finta pazza (1641), Monteverdi's L'incoronazione di Poppea (1643), and Cavalli's Egisto. There were published scenarios for most Venetian operas in the 1640s and $1650 \mathrm{~s}$.

The libretto was usually published by the librettist, but nearly half of the scenarios do not even mention the librettist's name on the title page, but prominently feature the theatre or its owner's name. ${ }^{67}$ The SS Giovanni e Paolo and the short-lived Novissimo theatres relied on the scenario as a publicity item more than any other theatre. Scenarios from about twenty early operas have survived (see appendix 3 for Rosand's list of Venetian opera scenarios.) Because of the disposable nature of the document, many more were probably destroyed, making it difficult to be able to say categorically when they went out of fashion. Although it had become standard practice to issue librettos before the opera opened, by the middle of the 1640 s, they became increasingly useful as publicity documents when opera began to receive press coverage in the 1660s. As Rosand points out, librettos often explained the plot in the same way scenarios had, apparently making them obsolete.

For each individual opera, this system of publicity was very effective, but in terms of creating a climate of wonder about the entire city of Venice and the industry of Venetian opera, it was necessary for news to travel to the rest of

67Rosand $(1989,339)$ notes: “... scenarios were not regularly published under the auspices of the librettist but were often the responsibility of the theatre management." 
Europe. Venice had a reputation as an exciting tourist destination, fostering a mystique like few other cities in Europe, or indeed the world. The private correspondence of those who visited Venice in these years is filled with awe at the treasures from antiquity, Renaissance masters of the art world, its canals, its associations with the mysterious east and its reputation for unbridled sexuality, particularly during Carnevale. In addition, Venice was the centre for European diplomacy and business as well as its first secular tourist destination, attracting thousands of wealthy English, French, German and Dutch visitors every year to Carnevale. During the Thirty Years' War (ca. 1618-48), when large parts of Europe were being laid waste, Venice was a haven for fleeing rulers and a neutral place for diplomats to conduct business, and became an important centre for negotiations to end the Thirty Years' War, a sort of de facto diplomatic United Nations avant la lettre. A number of opera audience members were foreign, and so it seems clear that the mail was a useful tool for a producer.

\section{The Postal System and Publicity}

The first opera-related publication to take advantage of the postal system was created for Strozzi's inaugural production at the Novissimo, one that strove not only to publicize the work itself, but also to reinforce the idea of Venice as a city of marvels. This publication was called the Cannocchiale per la finta pazza. ${ }^{68}$ An elaborate fifty-five-page publication printed around Easter (after the production had closed), written by Maiolino Bisaccioni, Count of Genoa and a member of the Accademia degli Incogniti, the Cannocchiale was specifically designed to bring the reader closer to the production. $\mathrm{He}$ writes:

I considered these days, that Sig. Giulio Strozzi's composition of the Finta pazza, the machines of Sig. Iacomo Torelli, and the music woven for them by Sig. Francesco Sacrati were a sky worthy of being contemplated by everyone, but so far from so many people that is would diminish the value for the many who came to view so noble an undertaking if one did not make it possible for everyone to see and admire it; the scenario was printed, and also the libretto, but the machines and the costumes and the actions remained far from the view of the audience, and thus unappreciated. ${ }^{69}$

He continues by hoping that the "eyes of those even in the most distant and secluded foreign countries enjoy in these pages what eyes and ears have enjoyed in this city, which in its every aspect surpasses the bounds of the

68 This document is discussed in detail by Rosand (1991, 94-98).

69 "Io considerava questi giorni, che la compositione del Sig Giulio Strozzi della Finta Pazza, le macchine ritrovate dal Sig. Iacomo Torelli, e la Musica orditavi sopra dal Sig. Francesco Sacrati, eran'un Cielo degno d'esser contemplato da tutti, ma così lontano à gran parte dalle genti, che era un toglier il pregio à tanti, che sono concorsi à si nobile fattura, se non si faceva commodo ad ognuno di vederla, \& ammirare, fù stampato il Scenario, e fù pur anco stampata l'Opera, ma le macchine, e gli habiti, e le comparse restavano lontane dalla vista delle genti, e però non lodate." (Preface, Il cannocchiale della finta pazza, 3-4, quoted in Rosand [1991, 415, appendix 1, 17a].) Transl. by the author of this article. 
marvellous."70 His statement suggests that the publication was intended to be mailed to distant places in order to create "buzz" about the city, since the opera had long since closed, and could not attract an audience. The Cannocchiale devotes a large amount of space to discussing audience reaction, suggesting that many attended three and four times, ${ }^{71}$ and that they sometimes even forgot they were in Venice because of the excellence of the scenic painting. ${ }^{72} \mathrm{He}$ concludes by claiming that:

[t] he public's desire to see it again never ended; and thus, however many times it was repeated, the place was crowded with people, and many were led to curse their own laziness when they arrived and had to leave because they could not find any place to sit. Nor did the long period between the end of Carnival and Easter lessen the desire on the city to see such an applauded work again, even though familiarity normally breeds contempt; and thus it was necessary to reopen the theater and perform it a number of times, which further spread the fame of this delightful spectacle to the cities of Italy and beyond, and was the reason that, quite exceptionally, Venice was filled ten days early with the crowds that normally gather for the devotions and ceremonies of Ascension Day. ${ }^{73}$

The effect of the publicity was triple-pronged: the Cannocchiale made the libretto a popular item (the second printing of the libretto contains a note from the publisher claiming that he was "forced ... by the avidity of the readers of this work to print it twice in one month"); La finta pazza, the work it lauded, went on to be produced more than any other opera in the seventeenth-century, particularly outside of Venice; and Venice became increasingly popular as a travel destination thanks in no small part to the existence of opera houses and their productions. ${ }^{74}$

The success of the Cannocchiale was followed the next year with Vincenzo Nolfi and Sacrati's Bellerofonte, the third Novissimo opera, (the second, Alcate by Marc'Antonio Tirabosco and Manelli, seems to have had little publicity). Bellerofonte had both a scenario and a libretto published beforehand. The scenario had a preface prepared by Torelli, which focussed on the machinery

70 "Godano con gli occhi sù queste carte anco gli esteri più remoti, e ritirati, quello di c'hanno goduto gli occhi, e gli orecchi in questa Città, che in ogni sua parte eccede i confini delle meraviglie." (Quoted and translated by Rosand [1991, 415, appendix 1, 17b].)

71 "Si dilettò con meraviglia chiunque v'andò ad essere spettatore, nè contento d'una e due volte, vi ritornò la terza e la quarta, e più ancora." (Rosand, 1991, 415, appendix 1, 17f)

72 Gli uditoro dimenticatisi d'essere in Venetia...." (Rosand 1991, 415, appendix 1, 17h).

73 "Non terminò il desiderio nel popolo di revederla, onde quante volte fü replicata, altre tante fù di numerosa gente ripieno il luogo, e sempre molti hebbero da biasimare la propria pigritia d'esser andati ad occupare i luoghi, dovendo partire senza trovar dove accomodarsi, nè il lungo tratto da gli ultimi giorni Carnovaleschi a $\mathrm{i}$ Paschali hà fatto cessar nella Città il desiderio di riveder opra così pregiata, $\mathrm{e}$ pure non è cosa più facile ne i popoli, che la domesticanza, ond'è stato necessario, di riaprir di nuovo il Theatro, e più volte rappresentarla, per lo che la fama sparsane alle Città d'Italia nel convitar gli esteri a sì dilettevole spettacolo è stato cagione, che Venetia fuor del uso già dieci giorni prima veda l'abondanza del popolo, che suol concorrere alla divotione, \& alla Sollennità che si celebra dell'Ascensione." (Il cannocchiale per la finta pazza, 54-55, quoted in Rosand [1991, 416, appendix 1, 17 1].)

${ }^{74}$ The increased popularity of Venice as a travel destination along with its decline as a manufacturing nation is noted by Cipolla $(1968,142-45)$. 
and the libretto, signed by Nolfi who explained the shortcomings of the text, claiming it was a rush job. The third publication, similar to the Cannocchiale per la finta pazza, was a "deluxe commemorative quarto volume" (Rosand 1991, 100) published apparently under the instructions of Torelli. ${ }^{75}$ It focuses on the scenic aspects of the production, and an elaborate account of the performance, including the entire text and ten engravings of scenery. ${ }^{76}$

The libretto for Venere gelosa, the first opera to be produced at the Novissimo after the departure of the three mainstays of the company, Strozzi, Renzi and Sacrati, was also published before the premiere and re-issued four times, in Venice and Padua, although no scenario seems to have been published. Torelli, the machine designer, issued a commemorative volume in 1644 entitled Apparati scenici per lo Teatro Novissimo di Venetia nell'anno 1644 d'inventione e cura di Iacomo Torelli di Fano. Although it does not refer to any specific opera, there are a large number of references to this work, even though it was released on January 24,1644 , almost a year after Venere gelosa closed.

In order for these commemorative volumes to have currency in the rest of Europe, they had to travel by post. Europe's first and most successful private postal service, Thurn \& Taxis, established in 1489, boasted that it could deliver a letter from Venice to Augsburg in six days. By the 1630s, there was a regular mail route from Amsterdam, through Frankfurt-am-Main, Augsburg, Innsbruck, Trento and Venice as well as several other places in between. ${ }^{77}$ According to Franco Rigo, the journey from Venice to Amsterdam took nineteen days. ${ }^{78}$ Despite this relatively quick (for the time) speed of delivery, the single letter was an inefficient means of publicizing opera, with just a single reader per letter.

The possibility of reaching multiple readers began with the improvement of the printing press in the $1620 \mathrm{~s}$. By a strange twist of fate, this new means of reaching a larger audience manifested in the inexpensive avviso, or tabloid, came into being because of the efficiency of the Inquisitori di Stato, the Venetian government's secret police. Gossip was a lucrative commodity in Venice, and the Inquisitori di Stato, who were created to guard state secrets and to report and prosecute any crime committed by a noble, regularly reported

75 The title page reads: "Il BELLERO FONTE: Drama Musicale Del Sigr Vicenzo Nolfi da $f$. RAPPRESENTATO NEL TEATRO NOVISSIMO IN VENETIA DA GIACOMO Torelli Da Fano Inuentore delli Apparati, DEDICATO Al Sermo. ferdinando Il Gran Duca di Toscana 1642."

76 The text of this is reprinted in Worsthorne (1954, appendix 5).

77 This circuitous route, and the order of the cities is the one taken by the postal service.

78 Archivio di Stato - Venezia, C.d.C., 64. Cited in Rigo $(1985,35)$ : "La corrispondenza ha seguito la via di Francoforte - Augusta - Trento - Mantova. La carrozza di Augusta aveva due percorsi stradali da effettuare: uno (quello preferito per i passaggeri) andava da Venezia - Padova - Vicenza - Verona - Trento - Bolzano - Innsbruck, l'altro (era scelto quando il viaggio riguardava le merci) andava da Venezia - Treviso - Castelfranco Veneto - Bassano - Borgo (qui si univa alla strada per Trento ed il viaggio riprendeva la via originaria).

"La carrozza Postale parte da Venezia il martedi sera, da Innsbruck la domenica mattina, da Augusta il mercoledi mattina (il martedi riposo), da Colonia il venerdi mattina, arrivo ad Amsterdam Domenica mattina. In totale sono 19 giorni." 
on the movements of public officials, local events, crime and punishment, military and diplomatic movements, and entertainment. Each Saturday, every agent filed a report called an avviso with the government. Initially, avvisi were hand-written documents, but the informants recognised the potential profitability of information and soon took advantage of Venice's printing presses to make multiple copies of their reports. As early as 1563 , Venetian printers were selling these avvisi on the Rialto Bridge for the low price of one "gazeta," a silver coin worth two soldi. The term gazette, used by modern newspapers is a reference to the coin that purchased an avviso. Avviso readers were unlike scholarly book-readers; they tended to be fashionable men and women who wanted to know what was talked about in society but had only a small amount of time to absorb it. By the time commercial operas became the rage in Venice, avvisi and newssheets were being sold on every street corner in Europe, and some of them included reports about the audiences who attended operas and the aristocrats who had written them.

Only a few avvisi have survived to be studied, because they were intentionally ephemeral documents, printed or written on poor quality paper, and designed to be thrown away after use. Nevertheless, there is one collection dating from 1660 that mentions opera performances. Il Rimino, a compilation of avvisi from Modena, Parma, Florence, Paris and Venice as well as various other centres, often mentions little more than the names and sponsors of operas, but they always reported on operas and the audience's reaction because they were public events that allowed otherwise discouraged interactions between foreign and native officials and rulers. Pompeo Molmenti records a French ambassador who advised a friend that:

you must not think that with ambassadors (it is wise to be vigilant about this), ministers from foreign lands must not enter into a relationship with magistrates; one must speak through third parties, or speak by signals at the opera, a circumstance that makes attending shows and the use of masks necessary to foreign ministers (Molmenti 1882, 408n2). ${ }^{79}$

Audience reaction, it seems, would have been noted to provide information to the censors and to the police.

An innovation introduced in Paris in 1631 by Théophraste Renaudot changed the newspaper industry in Venice; Renaudot, who had visited Venice in the 1620 s, created the Gazette de France, a journal with a slightly more practical tone. When he was made Commissioner-General under Louis XIII, he tried various methods of decreasing poverty and beggary in Paris; the Gazette de France was his most successful effort in this regard. Like the Venetian avvisi, it began life as a four-page book-like publication with a

79"Il ne faut pas croire que, avec les ambassadeurs (sévérité bien sage), les ministres étrangers ne soient pas dans une sorte de liaison avec les magistrats; on se parle par des tiers; on se dit bien des choses par des signes à l'Opéra, circonstance qui rend la fréquentation des spectacles et les usages du masque nécessaires aux ministres étrangers." 
circulation of less than one thousand, advertising goods and services, intended to "make, print, and to have printed and sold by those appropriate, news, gazette and accounts of all that has happened and is happening inside and outside the Kingdom" (Smith 1979, 29). His idea was to insert advertising supplements into the paper and small advertisements mixed in with the news that would pay for the publication and allow him to lower the cost of the paper, making it affordable to all. Thanks to this single idea, his circulation rose to 12,000 by 1672. The Gazette de France stayed in business until the nineteenth century, and is the prototype for the modern newspaper.

In January 1673, another new and extremely influential periodical appeared in Paris. Le Mercure galant was a periodical started by Jean Donneau de Visé, who went to great pains to have the new operas in Venice reported upon. From the point of view of operatic history, it is more valuable than any other single journal for developing an understanding of Venetian opera in the seventeenth-century. In its time, Le Mercure galant was widely read because it was the official publication of the French royal court. The original intention of Le Mercure galant's editors was to publish one issue every three months, but early in 1674, its founder, de Visé, became gravely ill and stopped publishing until in 1677; with the help of Pierre Corneille's brother Thomas (later librettist for Charpentier's Medée, 1691), the journal was revived as a monthly. Its influence on aristocratic French life, and by extension, the aristocratic life of all of Europe cannot be overstated, as it was published at court, and was clearly an instrument of political propaganda (Smith 1979, 30-51).

Beginning in August 1677, there was a great deal of coverage of music of all sorts, and the discussion was much more detailed and important than ever before. The (initially anonymous) Venetian correspondent wrote thirty pages in the form of a letter addressed to an anonymous "Madame" on the subject of the new operas in Venice, including names of librettists, composers, and vivid descriptions of the music and the theatrical machinery. Two years later, he wrote a series of articles on the San Salvatore theatre, on the opening of the lavish San Giovanni Grisostomo theatre, including the premiere of Pallavicino's inaugural Il Vespasiano, complete with a reprint of an aria from Pallavicino's Il Nerone, his second work at the same theatre.

In 1681 and 1683, the author signed the name Chassebras de Cramailles to a series of letters to Le Mercure galant, listing all the new operas performed during Carnevale. He provided a remarkably detailed description of the sumptuous San Giovanni Grisostomo theatre, commenting that "large theatres are destined for the operas that the nobles or others have made and composed at their own expense, more for their own entertainment than for the profit that they make from them, since ordinarily the latter does not make up half of the outlay." 80 His description in March, 1683 of the San Salvatore theatre- "very grand, very beautiful, all newly painted and gilded, and the most considerable in Venice"81_may have helped the reputation of the theatre; the following

80 Le Mercure galant, March 1683, 236-37, quoted in Saunders $(1985,16)$.

81 Le Mercure galant, March 1683, 271: “... fort grand, fort beau, tout peint et doré de neuf, et des 
year, he claimed that there was such demand for tickets to the opera that one had to reserve one's seat in the orchestra level two days in advance.

In 1687, a journal called Pallade Veneta, modelled on Le Mercure galant appeared in Venice. ${ }^{82}$ Entirely written by Francesco Coli, a book censor for the Inquisition from Lucca, this journal may have appealed to northern Italians from Florence, Padua, Modena and Lucca in its tone and its descriptions of events. Each issue of the journal is dedicated to a different noble, including Duke Ferdinando Gonzaga of Mantua, Grand Duke Cosimo III Medici of Tuscany, Cardinal Francesco Maria Medici, as well as several Venetian nobles-Tadeo and Francesco Barberini and Carlo Vincenzo Giovanelli. It was never mentioned in the Giornale de' Letterati d'Italia (Venice, 1710) though, suggesting that it was not a major force in moulding public opinion. Nevertheless, its contents may have reflected l'air du temps. The presumed superiority of Venetian opera in Pallade Veneta is interesting to note because it was precisely at this time that Naples and Paris were challenging Venice operatically for the first time. The tone adopted by Pallade Veneta may well reflect the beginning of the problem with eighteenth century opera: the sense of complacency coupled with an urgent demand for new operas, fuelled the tendency to create operas that seem formulaic.

\section{CONCLUSION}

The fact that Pallade Veneta did not seem to have been widely read suggests that although newspapers and other publicity items-librettos, scenarios, avvisi-may have been laterally helpful to Venetian operas, they may not have actually been the catalysts of Venetian operatic popularity. Instead, they seem to have happened at the same time, reflecting the need in European society for increased publicity in daily life. Thus, I contend that these works were not necessarily popular because of the quality of the operas themselves, but at least partly because people were convinced, by means of various kinds of advertising, promotion and journalistic "buzz," to await them before they knew anything about them. ${ }^{83}$ While this may seem an outlandish claim to make about early commercial opera, it is generally accepted in modern performing arts that publicity is the largest budget item. It is therefore not impossible that the value of publicity or promotion was recognised as a valuable force even in the seventeenth-century. There is, after all, a tendency in humans to confuse what we know or what we have been told-what we think we know-with what we like. Eleanor Selfridge-Field points out that publicity served as a means of influence from the earliest days, in her book, Pallade Veneta:

plus considérables de Venise. Il contient cinq rangs de palcs, trente trois à chacque rang." In Worsthorne (1954, 33n7).

82 This publication was edited, discussed and reprinted by Selfridge-Field (1985).

83Ellen Rosand $(1991,72)$ comments that the first commercial opera in Venice, Andromeda was "a rather disconnected series of episodes", and Petrobelli $(1965,129-30)$ comments on a similar lack of coherence. 
[p]ublicity had nothing whatsoever to do with freedom; to the contrary, it could be a tool of subjugation. Contrived ... as a substitute for conspicuous acts of repression and censorship, the typical seventeenth-century journal projected a worldview that suited the interests of its sponsors. (Selfridge-Field $1985,31)$

I am not suggesting there was a conspiracy between newspaper publishers and impresarios to create some kind of false consciousness, but I will suggest that even at this early stage, operas were not judged solely on the merits of their sets, performers, performances, scores, and librettos, and it would be naïve to suggest that an operatic performance is simply the convergence of these elements, despite the temptation to reach conclusions on that which we can study. Nevertheless, more than three hundred years after an event, what remains of these events cannot hope to recreate what the audience at the time experienced. The fame of scenic designers like Giacomo Torelli, or singers like Anna Renzi, demonstrates this contention. The wealth of visual effects, machinery, sets, lighting, transcendent singing by the prima donne and uomini can no longer have the effect on us that they had on their first audiences, and the relics we use to study these operas, the narrative and the music were always intended to be secondary to the spectacle. If the quality of these works were the sole criterion for their popularity, then the low-budget operas of Francesco Santurini should have failed both from a critical and popular perspective, given the shabbiness Ivanovich attributes to the sets, the costumes, the machinery, and the talents of the singers. At least from a critical perspective, they did not fail; Santurini knew what audiences could overlook in making a more inexpensive and accessible product. He expressed a worldview through his productions, just as the editors of the avvisi expressed theirs, and a worldview expressed publicly is a form of institutional influence. Santurini capitalized on free publicity.

Before commercial opera appeared, printed publicity had seldom, if ever been used to attract audiences to musical events; commedia dell'arte sold tickets and even produced their own publicity materials, but this was entertainment of a slightly different type, and decidedly lower class entertainment, as understood by the early modern Venetian. Despite the fact that it was entertainment from a different part of society, many of opera's methods of attracting audiences were borrowed from the commedia dell'arte, transferred to the medium most attractive to the middle and upper classes: journalism. ${ }^{84}$ If publicity had been used before 1637, then its effectiveness may have been mitigated by ennui; it was effective after 1637 because the recipients of the publicity accepted the dubious premise that if it was written and published, it must therefore be true.

It seems more than mere coincidence that the newspaper-a commercial form of institutional influence-appeared at the same time that commercial opera was exerting a similar kind of influence over what would come to be

84 For more on this, see Pirrotta $(1955,305-24)$. 
known as fashion. In London, Nicholas Bourne and Nathaniel Butter received a monopoly from the king to print foreign news legally in 1638 , including newes from "Italy, Germanie, Hungaria, Bohemia, the Palatinate, France, and the Low Countries," while Théophraste Renaudot created La Gazette de France in 1631 in Paris by the will of Richelieu. These two forms of communication-newspapers and opera-are similar in many ways, and they have a symbiotic relationship as well: newspapers needed news and operas were news. On the other hand, operas needed audiences, and avvisi, journals, accademia publications, and newspapers helped to create an air of the extraordinary to attract audiences.

If Venice at Carnevale was a sort of proto-Disneyland, then commercial opera was the greatest attraction of this Early Modern amusement park. Like all amusement parks though, its existence depended upon a sense of heightened reality: if people do not come or do not have fun, the mystique disappears. Even in the seventeenth-century, it was difficult to remain fashionable, and it took the power of the great propagandists of the day to create the mythology of the most magnificent opera house in Venice, the Grimani theatre San Giovanni Grisostomo. Chassebras de Cramailles, the (perhaps unwitting) spin-doctor of Venetian opera for Le Mercure galant, described it most beautifully in these terms:

[The SS Giovanni Grisostomo theatre is] the most beautiful and the most luxurious in the city. Five ranges of opera boxes, one upon the other, thirty-one in each range ring the auditorium. They are decorated with sculpted ornaments in gilded bas-relief, representing different sorts of antique vases, shells, roses, rosettes, flowers, leaves and other enrichments. Under and between each of the opera boxes are various human figures made of white marble, also in relief, and as large as life, holding up the pillars that separate the boxes.... The ceiling is painted depicting a gallery, and at one end is the coat of arms of the Grimani [the theatre's owners], beneath which is Glory surrounded by various divinities and children, and a garland of flowers. One hour before the show begins, the tableau of Venus on the ceiling retracts, and a chandelier with four fourteen-foot gold and silver branches descends. It contains a great coat of arms of Grimani family with a crown of fleurs-de-lis and pearl encrusted rays beneath. The chandelier boasts four grand candelabras with white wax that light up the room and continue burning until the curtain is raised and when this happens, it all vanishes and returns to its previous state. When the show is over, this machine reappears to illuminate the spectators and to give them means to leave without confusion. (Worsthrorne 1954, 34-35) 
Appendix 1. Boxes and prices at Venice's major theatres, 1630-78

\begin{tabular}{|l|l|l|l|l|}
\hline Year & Theatre & $\begin{array}{l}\text { Number } \\
\text { of Boxes }\end{array}$ & Price/annum & Total Income \\
\hline $1630-66$ & $\begin{array}{l}\text { SS Giovanni } \\
\text { e Paolo }\end{array}$ & 77 & & \\
\hline 1677 & $\begin{array}{l}\text { SS Giovanni } \\
\text { e Paolo }\end{array}$ & 160 & & \\
\hline after 1657 & S Cassiano & $\begin{array}{l}92(+6 \text { for } \\
\text { owners }\end{array}$ & 25 ducats & 2300 ducats \\
\hline $1650-57$ & S Apollinare & 48 & 20 ducats & 960 ducats \\
\hline 1673 & S Moisè & 145 & & \\
\hline 1678 & S Salvatore & 165 & & \\
\hline 1678 & $\begin{array}{l}\text { S Gio. } \\
\text { Grisostomo }\end{array}$ & 154 & & \\
\hline
\end{tabular}

Appendix 2. The Venetian monetary system

1 gazeta $=2$ soldi, $1 / 10 \mathrm{Vl}$

1 Venetian lire $(\mathrm{Vl})=20$ soldi

1 ducat $=6 \mathrm{Vl}, 4$ soldi

1 reale $=8 \mathrm{Vl}$

1 scudo d'argento $=9 \mathrm{Vl} 6$ soldi

1 scudo $=14 \mathrm{Vl}$

1 ongaro $=15 \mathrm{Vl}, 10$ soldi $(1653), 16 \mathrm{Vl}(1665)$

1 zecchino $($ cecchino $)=17 \mathrm{Vl}$

1 doble $=28 \mathrm{Vl}$ 
Appendix 3. Venetian opera scenarios (title, date, theatre, publisher) (from Rosand 1989, 335-46)

1. La Delia, November 5, 1638, SS Giovanni e Paolo, Giulio Strozzi

2. Le nozze di Teti e di Peleo, 1639, San Cassiano, ?

3. Le nozze d'Enea in Lavinia, 1640, SS Giovanni e Paolo, Claudio Sartori?

4. La Didone, 1641, San Cassiano, Miloco

5. La finta pazza, January 14,1641 , Teatro Novissimo, Surian

6. Bellerofonte, 1642, Teatro Novissimo, Surian

7. Narciso et Ecco, after January 1643, San Giovanni e Paolo, ?

8. Alcate, after February 13, 1642, Teatro Novissimo,?

9. La coronatione di Poppea, 1643?, SS Giovanni e Paolo, Claudio Sartori 10. Egisto, 1643, San Cassiano, Miloco

11. Il Prencipe giardiniero, before Dec. 30, 1643?, SS Giovanni e Paolo, Salis

12. Deidamia, before January 1644, Novissimo, Leni e Vecellio

13. Ulisse errante, 1644, SS Giovanni e Paolo, Pinelli

14. Ercole in Lidia, 1645, Teatro Novissimo, Vecellio e Leni

15. Romolo e Remo, before February 5, 1645, SS Giovanni e Paolo, ?

16. Gli acidenti del vitorioso Goffredo, 1648, Santi Apostoli, Valvasense

17. Eritrea, 1652, San Apollinare,?

18. Helena rapita da Theseo, 1653, SS Giovanni e Paolo, ? (printed with libretto) 19. Erismena, 1655, San Apollinare, ? 


\section{REFERENCE LIST}

Bianconi, Lorenzo. 1987. Music in the Seventeenth Century. Cambridge: Cambridge University Press.

Bianconi, Lorenzo, and Giorgio Pestelli. 1998. Opera Production and its Resources. Chicago: University of Chicago Press.

Bianconi, Lorenzo, and Thomas Walker. 1984. "Production, Consumption and Political Function of Seventeenth Century Opera." Early Music History 4: 209-96.

Biggi, Maria Ida. 2000. "Torelli a Venezia." In Giacomo Torelli: invenzione scenica nell'Europa barocca, 33-40. Fano: Fondazione Cassa di Risparmio di Fano.

Bjurström, Per. 1961. Giacomo Torelli and Baroque Stage Design. Stockholm: Almqvist \& Wiksell.

Cipolla, Carlo. 1968. "The Economic Decline of Italy." In Crisis and Change in the Venetian Economy in the Sixteenth and Seventeenth Centuries. Debates in Economic History, ed. Brian Pullan, 126-45. London: Methuen.

Giazotto, Remo. 1967. "La guerra dei palchi." Nuova rivista musicale Italiana 1, no. 2 (July-August): 245-86, 465-508.

Glixon, Beth, and Jonathan Glixon. 1992. "Marco Faustini and Venetian Opera Production in the 1650s: Recent Archival Discoveries." The Journal of Musicology 10, no. 1 (Winter): 48-73.

Glover, Jane. 1975. "The Teatro Sant' Apollinare and the Development of Seventeenth-century Venetian Opera." PhD diss., Oxford University.

Ivanovich, Cristoforo. 1993 [1687]. Memorie teatrali di Venezia. Ed. Norbert Dubowy. Repr. Roma: Libreria Musicale Italiana.

Lane, Frederic C. 1973. Venice: A Maritime Republic. Baltimore: The Johns Hopkins University Press.

Leclerc, Hélène. 1987. Venise et l'avènement de l'opéra public à l'Âge baroque. Paris: A. Colin.

Logan, Oliver. 1972. Culture and Society in Venice, 1470-1790: The Renaissance and Its Heritage. New York: Scribner, London: B. T. Batsford.

Mamy, Sylvie. 1996. La musique à Venise et l'imaginaire français des Lumières: d'après les sources vénitiennes conservées à la Bibliothèque nationale de France. Paris: Bibliothèque nationale de France.

Mancini, Franco, Maria Teresa Muraro, and Elena Povoledo, eds. 1995. I teatri del Veneto: Venezia, teatri effemeri e nobili imprenditori. Venice: Corbo e Fiore.

Mangini, Nicola. 1974. I teatri di Venezia. Milano: Mursia.

Molmenti, Pompeo. 1882. La storia di Venezia nella vita privata. Venice: F. Ongania.

Morelli, Giovanni, and Thomas Walker. 1976. "Tre controversie intorno al San Cassiano." In Venezia e il melodramma nel seicento, ed. Maria Teresa Muraro, 97-120. Florence: Leo S. Olschki Editore.

Papadopoli-Aldobrandini, Nicolo. 1907. Le monete di Venezia descritte ed illustrate. Venice: Tipografia Libraria Emiliana. 
Petrobelli, Pierluigi. 1965. "L'Ermiona' di Pio Enea degli Obizzi ed i primi spettacoli d'opera veneziani." Quaderni della Rassegna musicale 3: $125-41$.

Pirrotta, Nino. 1955. "Commedia dell'arte and Opera." Musical Quarterly 41: 305-24.

1984. Music and Culture in Italy from the Middle Ages to the Baroque. Cambridge: Harvard University Press.

Prunières, Henri. 1931. Cavalli et l'opéra vénitien au XVII siècle. Paris: Les Éditions Rieder.

Rigo, Franco. 1985. Venezia Le Vie della Posta. Venice: Edizione Grafiche "La Press."

Rosand, Ellen. 1989. "The Opera Scenario, 1638-1655: A Preliminary Survey." In In cantu et in sermone: for Nino Pirrotta on his 80th birthday, ed. Fabrizio Della Seta, 335-46. Franco Piperno, Florence: Leo S. Olschki.

. 1991. Opera in Seventeenth Century Venice. Berkeley: University of California Press.

Saunders, Harris Sheridan Jr. 1985. "The Repertoire of a Venetian Opera House (1678-1714): The Teatro Grimani di San Giovanni Grisostomo." PhD diss., Harvard University.

Selfridge-Field, Eleanor. 1985. Pallade Veneta: Writings on Music in Venetian Society, 1650-1750. Venice: Edizioni Fondazione Levi.

Smith, Anthony. 1979. The Newspaper: An International History. London: Thames and Hudson.

Vaumorière, Pierre d'Ortigue, Sieur de. 1709. Lettres sur toutes sortes de sujets. 5th ed. Paris: J. Guignard.

Wolff, Hellmuth Christian. 1975. Die Venezianische Oper in Zweiten Hälfte des 17 Jahrhunderts. Bologna: Arnaldo Forni Editore.

. 1978. "Italian Opera From the Later Monteverdi to Scarlatti." In The New Oxford History of Music, eds. Sir Anthony Lewis and Nigel Forune, trans. Marina Branscombe, 1-72. Oxford: Oxford University Press.

Worsthorne, Simon Towneley. 1954. Venetian Opera in the Seventeenth Century. Oxford: Clarendon Press.

\footnotetext{
Abstract

Commercial operas of seventeenth-century Venice, the earliest public operas, are generally described as rigorously literary from $1637-1660$. Various tools, including sets, machines, and musical forms helped audiences from various classes and places understand this Venetian Carnevale entertainment. The goal-to create a commercial entertainment industry that reflected and highlighted the wonders of Venice-was identified early in the history of Venetian commercial opera. This paper seeks to define the extent to which nascent commercial enterprises like newspapers, the mail, publishing, and advertising defined the content and nature of these early operatic works.
} 


\section{Résumé}

On décrit généralement les opéras commerciaux du XVII ${ }^{\mathrm{e}}$ siècle à Venise, soit les premiers opéras publics, comme étant rigoureusement littéraires entre 1637 et 1660 . Divers moyens, dont les décors, les machines et les formes musicales, aidaient les auditeurs issus de classes et de lieux différents à comprendre ces divertissements typiques du carnaval de Venise. Leur objectif - créer un divertissement commercial qui reflète et souligne les merveilles de Venise - a rapidement été cerné par l'histoire de l'opéra commercial vénitien. Le présent article cherche à définir jusqu'à quel degré les entreprises commerciales naissantes, comme les journaux, la poste, l'édition et la publicité, définissaient le contenu et la nature de ces premières œuvres lyriques. 